\title{
The impact of MM5 and WRF meteorology over complex terrain on CHIMERE model calculations
}

\author{
A. de Meij ${ }^{1, *}$, A. Gzella ${ }^{1}$, C. Cuvelier ${ }^{1}$, P. Thunis ${ }^{1}$, B. Bessagnet ${ }^{2}$, J. F. Vinuesa ${ }^{1}$, L. Menut ${ }^{3}$, and H. M. Kelder ${ }^{4}$ \\ ${ }^{1}$ European Commission - DG Joint Research Centre, Institute for Environment and Sustainability, 21020 Ispra, Italy \\ ${ }^{2}$ INERIS, Institut National de l'Environnement industriel et des Risques, Parc Technologique ALATA, 60550 \\ Verneuil-en-Halatte, France \\ ${ }^{3}$ Laboratoire de Météorologie Dynamique, Institut Pierre-Simon Laplace, Ecole Polytechnique, Palaiseau, France \\ ${ }^{4}$ Department of Applied Physics, Eindhoven University of Technology, Eindhoven, The Netherlands \\ *now at: Energy, Environment and Water Research Centre, The Cyprus Institute, 20 Kavafi Street, 1645, Nicosia, Cyprus
}

Received: 17 November 2008 - Published in Atmos. Chem. Phys. Discuss.: 26 January 2009

Revised: 22 June 2009 - Accepted: 23 August 2009 - Published: 11 September 2009

\begin{abstract}
The objective of this study is to evaluate the impact of meteorological input data on calculated gas and aerosol concentrations. We use two different meteorological models (MM5 and WRF) together with the chemistry transport model CHIMERE. We focus on the Po valley area (Italy) for January and June 2005.

Firstly we evaluate the meteorological parameters with observations. The analysis shows that the performance of both models in calculating surface parameters is similar, however differences are still observed.

Secondly, we analyze the impact of using MM5 and WRF on calculated $\mathrm{PM}_{10}$ and $\mathrm{O}_{3}$ concentrations. In general CHIMERE/MM5 and CHIMERE/WRF underestimate the $\mathrm{PM}_{10}$ concentrations for January. The difference in $\mathrm{PM}_{10}$ concentrations for January between CHIMERE/MM5 and CHIMERE/WRF is around a factor $1.6\left(\mathrm{PM}_{10}\right.$ higher for CHIMERE/MM5). This difference and the larger underestimation in $\mathrm{PM}_{10}$ concentrations by CHIMERE/WRF are related to the differences in heat fluxes and the resulting PBL heights calculated by WRF. In general the PBL height by WRF meteorology is a factor 2.8 higher at noon in January than calculated by MM5. This study showed that the difference in microphysics scheme has an impact on the profile of cloud liquid water (CLW) calculated by the meteorological driver and therefore on the production of $\mathrm{SO}_{4}$ aerosol.

A sensitivity analysis shows that changing the Noah Land Surface Model (LSM) in our WRF pre-processing for the 5-layer soil temperature model, calculated monthly mean
\end{abstract}

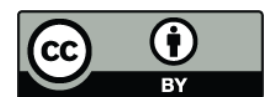

Correspondence to: A. de Meij (a.demeij@cyi.ac.cy)
$\mathrm{PM}_{10}$ concentrations increase by $30 \%$, due to the change in the heat fluxes and the resulting PBL heights.

For June, $\mathrm{PM}_{10}$ calculated concentrations by CHIMERE/MM5 and CHIMERE/WRF are similar and agree with the observations. Calculated $\mathrm{O}_{3}$ values for June are in general overestimated by a factor 1.3 by CHIMERE/MM5 and CHIMERE/WRF. High temporal correlations are found between modeled and observed $\mathrm{O}_{3}$ concentrations.

\section{Introduction}

Aerosols play an important role in health effects (respiratory and cardiovascular disease, Moshammer and Neuberger, 2003), pollution, eutrophication/acidification of aquatic and terrestrial ecosystems and radiative forcing (absorbing and scattering of solar radiation, Kaufman et al., 2002). Groundbased measurement networks provide information about the atmospheric conditions at a particular time and location and can not be used alone for policymaking to establish effective strategies for air emissions reduction policy. The atmospheric chemistry-transport-dispersion models (CTMs) have the advantage that they can be used to complement monitoring data, assess the effects of future changes in gas, aerosol and aerosol precursor emissions and to study the impact of source pollutants on air quality elsewhere.

Each atmospheric chemistry transport model includes a specific sequence of operations, with specific input data, such as emissions and meteorology to calculate gas and aerosol concentrations. Uncertainties in the estimation of gases and primary aerosols in the emission inventories (De Meij et

Published by Copernicus Publications on behalf of the European Geosciences Union. 
al., 2006), aerosol dynamics (physical transformations, dry and wet removal, transport), meteorological factors (temperature, humidity, wind speed and direction, precipitation, cloud chemistry, vertical mixing), the impact of orography on meteorological parameters (Carvalho et al., 2006), the impact of horizontal resolution of meteorology on model calculations (Baertsch-Ritter et al., 2004; Menut et al., 2005) and the fact that the formation of aerosols are known to be nonlinearly dependent on meteorological parameters such as temperature, humidity and vertical mixing (Haywood and Ramaswamy, 1998; Penner et al., 1998; Easter and Peters, 1994) and the concentrations of precursor gases (West et al., 1998), all contribute to uncertainties in the calculated gas and aerosol concentrations. A good estimate of meteorological variables in the meteorological datasets is therefore crucial for calculating gas and aerosol impacts on air quality and climate change, and evaluating coherent reduction strategies.

The main objective of this study is to evaluate the impact of meteorological input data on calculated aerosol concentrations. We study the central Po valley (northern Italy), which has been identified as one of the two main areas (together with Benelux) where pollutant levels will remain problematic by 2020 , according to the different scenarios carried out in the frame of the Clean Air for Europe (CAFE) programme by the International Institute for Applied System Analysis (IIASA). We focused our analysis on the year 2005 and particularly on a winter month (January 2005) and a summer month (June 2005), to highlight the impact of different meteorological conditions prevailing in winter and summer on the calculated gas and aerosol concentrations. To this end we performed simulations with the CHIMERE model (http://www.lmd.polytechnique.fr/CHIMERE/), using two different meteorological models, the Mesoscale Meteorological model (MM5, Grell et al., 1994) and the Weather Research and Forecasting model (WRF, (http://wrf-model. org/index.php). So far, work has been done in comparing MM5 and WRF simulated meteorological parameters with observations (Zhong et al., 2007; Michelson and Bao, 2006), and the impact of MM5 and WRF on ozone calculated values (Soong et al., 2006). To our knowledge, no studies have been performed in evaluating the impact of MM5 and WRF on calculated aerosol species.

Section 2 deals with the description of the simulations, the air chemistry transport model, the meteorological models and the emission inventory. In Sect. 3 a description of the measurement data is given. In Sect. 4 the results are presented. We discuss the results in Sect. 5 and we finish with conclusions in Sect. 6.

\section{Methodology}

The CHIMERE model (Bessagnet et al., 2004) is used to simulate air quality over the Po valley area for January and June 2005 based on the meteorological data sets provided by MM5 and WRF. More details regarding the atmospheric chemistry and meteorological models are given in Sect. 2.1 and 2.2 , respectively.

We start our study by evaluating the meteorological parameters temperature, relative humidity, wind direction and wind speed, calculated by both weather prediction models. The modelling results were compared with meteorological observations for the year 2005, given by the monitoring network of the Regional Agencies for Environment Protection in Lombardy (Agenzia Regionale per la Protezione dell' Ambiente, ARPA Lombardia, http://www.arpalombardia.it, last accessed 12 March 2009).

Then we evaluate the calculated aerosol $\left(\mathrm{PM}_{10}\right)$ and ozone $\left(\mathrm{O}_{3}\right)$ concentrations, using the CHIMERE model with MM5 and WRF results as input data, by comparing the model calculated concentrations with measurements from the EMEP station and measurements from the ARPA networks (Lombardy and Veneto). We focus on $\mathrm{PM}_{10}$ and $\mathrm{O}_{3}$ because these pollutants have more adverse health effects than other pollutants and are therefore commonly measured at most of the air quality monitoring stations. More details regarding the measurement networks are given in Sect. 3 .

Four simulations are performed with CHIMERE, two simulations with MM5 meteorology (CHIMERE/MM5) for January 2005 and June 2005, and two simulations with WRF meteorology (CHIMERE/WRF) for January and June 2005.

The meteorology has been created for the whole year 2005 , with no nudging to the observations of the meteorological stations.

For the four simulations, a spin-up time of 4 days is applied in order to initialize the model.

\subsection{Description CHIMERE model}

CHIMERE is an off-line chemistry transport model, driven by a meteorological driver, such as MM5 (Grell et al., 1994) or WRF (http://wrf-model.org/index.php, last accessed 12 March 2009).

The complete chemical mechanism in CHIMERE is called MELCHIOR1 (Lattuati, 1997, adapted from the original EMEP mechanism, Hov et al., 1985), which describes more than 300 reactions of 80 species. The reduced mechanism MELCHIOR2 includes 44 species and about 120 reactions, derived from MELCHIOR1 (Derognat et al., 2003).

Processes like chemistry, transport, vertical diffusion, photochemistry, dry deposition, in-cloud and below cloud scavenging and $\mathrm{SO}_{2}$ oxidation in clouds are included in the model. The thermodynamic equilibrium model ISORROPIA (Nenes et al., 1998) is used to calculate the equilibrium partitioning of the gas-liquid-solid aerosol phase of various aerosols compounds (e.g. $\mathrm{SO}_{4}^{=}, \mathrm{NO}_{3}^{-}, \mathrm{NH}_{4}^{+}, \mathrm{Na}^{+}, \mathrm{Cl}^{-}$). An overview of the processes and references is given in Table 1. More details regarding the parameterizations of the above mentioned processes are described in Bessagnet et al. (2004) and references therein. 
Table 1. Overview of the chemical and physical processes which are included in the air chemistry transport model CHIMERE. For a more detailed description of the processes in CHIMERE, see Bessagnet et al. (2004).

\begin{tabular}{ll}
\hline Process type & Reference \\
\hline Chemistry & MELCHIOR2, based on Lattuati (1997) \\
$\begin{array}{l}\text { Dry deposition } \\
\text { Photolysis rate constants }\end{array}$ & Seinfeld and Pandis (1998) \\
& Tropospheric Ultraviolet Visible module (TUV), Madronich and \\
Wet deposition & Flocke (1998) \\
In cloud and below cloud scavenging of gases and & Guelle et al. (1998) and Tsyro (2002) \\
aerosols: & \\
Aerosols & ISORROPIA, Nenes et al. (1998) \\
Coagulation & Fuchs (1964) \\
Nucleation & Kulmala et al. (1998) \\
Condensation/evaporation & Yes \\
Cloud effects on photolysis rates & Yes, see Bessagnet et al. (2004) \\
Transport & Parabolic Piecewise Method (PPM), Colella and Woodward (1984) \\
Vertical diffusion & Troen and Mahrt (1986) \\
Turbulent transport & Stull (1988) \\
Cloud chemistry of $\mathrm{SO}_{2}$ oxidation by $\mathrm{H}_{2} \mathrm{O}_{2}$ and & Yes \\
$\begin{array}{l}\mathrm{O}_{3} \\
\text { Anthropogenic and Biogenic aerosol formation }\end{array}$ & Yes, Anthropogenic yields come from Grosjean and Seinfeld (1989), \\
& Moucheron and Milford (1996), Odum et al. (1996, 1997) and Schell \\
& et al. (2001). \\
Vertical structure & Biogenic aerosol yields for terpene oxidation according to Pankow et \\
\hline
\end{tabular}

The lateral boundary conditions of gas species are monthly average values and are taken from the INCA model (http:// www-lsceinca.cea.fr/welcome_real_time.html, last accessed 12 March 2009). The boundaries conditions of aerosols are taken from the monthly mean aerosol concentrations provided by the larger scale model GOCART (Ginoux et al., 2001, 2004).

CHIMERE consists of 8 hybrid sigma pressure levels, up to $500 \mathrm{hPa}( \pm 5500 \mathrm{~m})$.

The domain (approximately $300 \times 300 \mathrm{~km}$, centred at $45.0^{\circ} \mathrm{N}, 10.0^{\circ} \mathrm{E}$ ) covers most of the Po Valley, Italy, including southern part of the Alps, see Fig. 1.

\subsection{Description meteorological input}

The PSU/NCAR mesoscale model MM5 (3.7.4) is a limitedarea, non-hydrostatic or hydrostatic, terrain following sigmacoordinate model designed to simulate or predict mesoscale and regional scale atmospheric circulations (Grell et al., 1994).

The Advanced Research WRF system (WRF-ARW V2.2) can be used as an alternative meteorological driver for MM5 in the air quality modelling. It is considered by NCAR as the successor of MM5, since further development of MM5 will come to an end in favour of WRF (see NCAR websites).

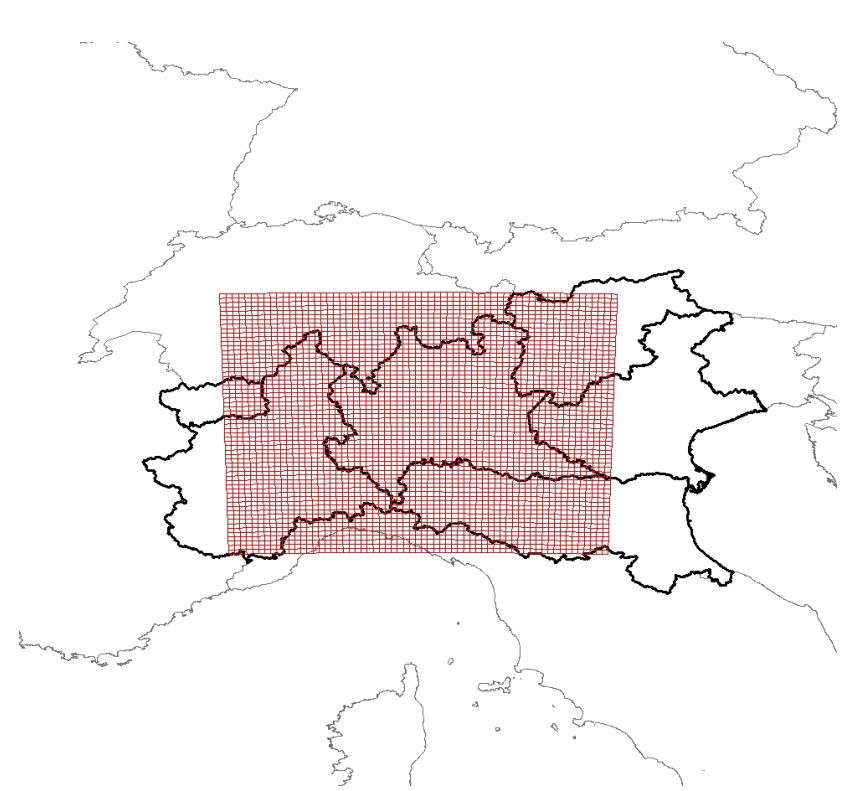

Fig. 1. Map of the location of the model domain in North Italy (centred at $45.0^{\circ} \mathrm{N}, 10.0^{\circ} \mathrm{E}$ ), which covers most of the Po valley, including southern part of the Alps. 
The meteorological data sets used for the study were created within the Po valley air quality Model Inter-comparison (POMI) exercise, which is coordinated by the Institute of Environment and Sustainability, JRC, Ispra, Italy (http://aqm. jrc.it/POMI/, last accessed 12 March 2009). The POMI exercise is focused on the area of the Northern Italy and two nested domains are set up there for meteorological data. WRF operates on the $5 \mathrm{~km}$ and $2.5 \mathrm{~km}$ resolution domains (one-way nested) and MM5 - on the $6 \mathrm{~km}$ and $2 \mathrm{~km}$ resolution domains (two-way nested).

Both MM5 and WRF use meteorological initial conditions and lateral boundary conditions from $6 \mathrm{~h}$ analyses from the NCEP Global Final (FNL) Analyses. Data produced during pre-processing and modelling simulations of MM5 and WRF are in the Lambert conformal projection. Both models have been set up to compute Sea Surface Temperature (SST) varying in time with 1 -h output time resolution. The time step of output data has been set to $1 \mathrm{~h}$ as well in both cases.

However, it should be noticed that the choice of the parameterization in MM5 and WRF is not always the same. The choice of the model setup in MM5 and WRF is based on previous studies (i.e. for WRF: Kesarkar et al., 2007; Guerrero et al., 2008) and recommendations by NCAR. The main differences between the MM5 and WRF parametrization are related to PBL schemes and microphysics. The settings of the meteorological models are given in Table 2.

\subsection{Emission data}

In this study we use the City Delta III project (http://aqm. jrc.it/citydelta, last accessed 12 March 2009) emission inventory, which has been used in recent studies Vautard et al. (2007) and Thunis et al. (2007). A detailed description of the emission inventory can be found in Cuvelier et al. (2007).

\section{Description measurement data sets}

The meteorological parameters provided by MM5 and WRF are compared with the observations from the EMEP measurement station Ispra (Italy) and from monitoring stations of the ARPA Lombardia network. The aerosol concentrations calculated by CHIMERE are compared with the aerosol measurements from the same or closely located air quality monitoring sites of the EMEP (Ispra, Italy) and ARPA networks (Lombardy, Veneto). The names of the stations for which we have meteorological data and $\mathrm{PM}_{10}$ data available are: Ispra (45.48 ${ }^{\circ}$ lat, $8.63^{\circ}$ lon), Cantu (45.74 ${ }^{\circ}$ lat, $9.13^{\circ}$ lon $)$, Erba (45.79 ${ }^{\circ}$ lat, $9.20^{\circ}$ lon), Mantova $\left(45.16^{\circ}\right.$ lat, $10.80^{\circ}$ lon $)$ and Castelnovo Bariano (45.03 lat, $11.29^{\circ}$ lon $)$, Sermide $\left(45.01^{\circ}\right.$ lat, $11.29^{\circ}$ lon).

To have a broader view on measured ozone concentrations for comparison purposes, additional air quality monitoring sites (not collocated with meteorological stations) are taken into account from ARPA network (Lombardy). The names of the stations are Osio Sotto $\left(45.63^{\circ}\right.$ lat, $9.60^{\circ}$ lon $)$, Gambara (45.25 ${ }^{\circ}$ lat, $10.29^{\circ}$ lon), Corte de Cortesi $\left(45.27^{\circ}\right.$ lat, $10.00^{\circ}$ lon $)$, Marmirolo Fontana $\left(45.12^{\circ}\right.$ lat, $10.44^{\circ}$ lon $)$, Lecco $\left(46.00^{\circ}\right.$ lat, $9.28^{\circ}$ lon $)$, Varese $\left(45.63^{\circ}\right.$ lat, $8.88^{\circ}$ lon $)$, Chiavenna $\left(46.32^{\circ}\right.$ lat, $9.40^{\circ}$ lon $)$ and Milano $\left(45.49^{\circ}\right.$ lat, $9.24^{\circ}$ lon). All air quality monitoring sites are characterized as background stations (including urban and suburban background), which is essential for comparison with the regional scale modelling results. More details regarding the different networks are given below.

\subsection{EMEP measurement site Ispra}

The EMEP measurement station at Ispra, Italy $\left(8.6^{\circ} \mathrm{E}\right.$, $45.8^{\circ} \mathrm{N}$ ) belongs to the Co-operative Programme for Monitoring and Evaluation of the Long-range Transmission of Air Pollutants in Europe (EMEP), which evaluates air quality in Europe by operating a measurement network, as well as performing model assessments (http://www.emep.int/, last accessed 12 March 2009). This EMEP station, situated at the eastern side of the Lago Maggiore at the foothills of the Alps, is located on the premises of the Joint Research Centre, Ispra (Italy). Concentrations of carbon monoxide (CO), ozone $\left(\mathrm{O}_{3}\right)$ and secondary aerosol precursors $\left(\mathrm{SO}_{2}, \mathrm{NO}_{\mathrm{x}}\right)$ are continuously monitored (http://ccu.jrc.it/, last accessed 12 March 2009). Daily aerosol samples are collected on quartz fibre filters to determine $\mathrm{PM}_{10}$ and $\mathrm{PM}_{2.5}$ concentrations and chemical compositions $\left(\mathrm{SO}_{4}^{=}, \mathrm{NH}_{4}^{+}, \mathrm{NO}_{3}^{-}\right.$, black carbon). Rain water samples are also collected to assess the aerosol wet deposition. In addition, $\mathrm{PM}_{10}$ concentration, aerosol size distribution in the range $8 \mathrm{~nm}-10 \mu \mathrm{m}$, and aerosol absorption coefficient are continuously monitored.

One of the artefacts occurring with the main filter type (quartz) used by the Ispra EMEP station, is the evaporation of ammonium nitrate at higher temperatures. Temperatures exceeding $20^{\circ} \mathrm{C}$ cause complete $\mathrm{NH}_{4} \mathrm{NO}_{3}$ evaporation from the quartz filter, a loss of $100 \%$; and a loss of about $25 \%$ for $\mathrm{NH}_{4}^{+}$, depending on the $\left(\mathrm{NH}_{4}\right)_{2} \mathrm{SO}_{4} / \mathrm{NH}_{4} \mathrm{NO}_{3}$ ratio measured on the filter. Temperatures between 20 and $25^{\circ} \mathrm{C}$ could lead to a loss of $50 \%$ of the nitrate aerosol (Schaap et al., 2003, 2004a). Therefore almost all reported summer $\mathrm{NH}_{4} \mathrm{NO}_{3}$ and $\mathrm{NH}_{4}^{+}$concentrations present only a lower limit, rather than a realistic concentration.

\subsection{ARPA}

Monitoring data of the ARPA networks (Agenzia Regionale per la Protezione dell' Ambiente) in Lombardy (http:// ita.arpalombardia.it/ita/index.asp, last accessed 12 March 2009) and Veneto (http://www.arpa.veneto.it, last accessed 12 March 2009) are used for comparison of meteorological variables (temperature, relative humidity, precipitation, wind speed and wind direction) with MM5 and WRF calculated meteorological parameters, as well as $\mathrm{PM}_{10}$ and $\mathrm{O}_{3}$ measured values with calculated model concentrations. 
Table 2. Overview of the WRF and MM5 parameterisations, which are used to create the meteorological input for CHIMERE.

\begin{tabular}{lll}
\hline Parameter & WRF & MM5 \\
\hline Integration time step [s] & 30 & 18 \\
Radiation calculation frequency [min] & 5 & 30 \\
Snow cover effects & Yes (Noah) & Yes (Noah) \\
Cloud effect on radiation & Yes & Yes \\
Microphysics & WSM6 (mix phase) (Hong and Lim, 2006) & 4 (simple ice) (Dudhia, 1989) \\
Cumulus scheme & None & None \\
PBL & YSU (MRF successor) (Hong et al., 2006) & MRF (Hong and Pan, 1996) \\
Radiation & RRTM (Mlawer et al., 1997) & RRTM (Mlawer et al., 1997) \\
LSM & Noah (Chen and Dudhia, 2001) & Noah (Chen and Dudhia, 2001) \\
Surface Layer & Monin-Obukhov & Monin-Obukhov \\
\hline
\end{tabular}

Air quality data from four monitoring stations of ARPA networks (three from Lombardy and one from Veneto) collocated with meteorological monitoring stations are used in this work: Erba, Cantu, Mantova and Castelnovo Bariano.

On the monitoring site of Erba concentrations of carbon monoxide $(\mathrm{CO})$, ozone $\left(\mathrm{O}_{3}\right)$ and secondary aerosol precursors $\left(\mathrm{SO}_{2}, \mathrm{NO}_{\mathrm{x}}\right)$ are continuously measured as well as $\mathrm{PM}_{10}$ levels (using TEOM with correction factors). In Cantu the $\mathrm{PM}_{10}$ concentrations are measured using beta absorption method and apart from this continuous data about $\mathrm{CO}, \mathrm{O}_{3}$ and $\mathrm{NO}_{\mathrm{x}}$ are being collected. In Mantova (S. Agnese) only $\mathrm{NO}_{2}, \mathrm{NO}, \mathrm{CO}$ and $\mathrm{PM}_{10}$ (using TEOM with correction factors) are measured.

On the monitoring station of Castelnovo Bariano (ARPA Veneto) concentrations of secondary aerosol precursors $\left(\mathrm{SO}_{2}, \mathrm{NO}_{\mathrm{x}}\right)$ as well as $\mathrm{PM}_{10}$ are continuously measured, using respectively fluorescence, chemiluminescence and gravimetric methods. Hourly meteorological data (for validation purposes) for this monitoring station are not available on the website of ARPA Veneto. Therefore the supporting meteorological data were taken from the monitoring station Sermide (ARPA Lombardia) which is located in the distance of about $2.5 \mathrm{~km}$ from Castelnovo Bariano.

All of the stations used for the comparison of modelled $\mathrm{O}_{3}$ concentrations with measurements are located in Lombardy. They operate within ARPA network and measure ozone concentrations using the UV absorption method.

\section{Results}

Firstly we evaluated the two meteorological datasets by comparing the calculated meteorological parameters with observations. Secondly we performed an evaluation of the impact of using two meteorological models in the CHIMERE model on calculated $\mathrm{PM}_{10}$ and $\mathrm{O}_{3}$ concentrations.

\subsection{Meteorology}

The evaluation of the modelled meteorological datasets is based on the observations from five monitoring stations located in Lombardy, Italy: Ispra, Mantova, Cantu, Erba and Sermide, using data given by ARPA Lombardia network. The following meteorological parameters were evaluated: temperature on the 2 meters level (data available for all stations), wind speed and direction (data available for two stations), as well as relative humidity and rain (data for four stations). The calculated statistics are: BIAS error, root mean square error (RMSE), standard deviation (SD) and the coefficient of determination ( $\mathrm{R}$ squared). For the wind direction data the mean absolute error (MAE) was calculated and the wind roses were analyzed. For the precipitation data the sums of observed and modelled amount of rain were calculated for each of the analyzed periods. Apart from this a capability of capturing the precipitation events by the models was evaluated using following hit rate statistics: probability of detection (POD), false alarm (FA), frequency BIAS (FBI), Hansen-Kuipers score (HKS) and odds ratio (OR) (Stephenson, 2000; Goeber and Milton, 2001). For detailed description of the formulas used to calculate statistics see Appendix. The analysis was performed for the annual means (year 2005) with the focus on winter (January 2005) and summer (June 2005) mean. In Sect. 4.1.5 we evaluate the vertical profile of the potential temperature calculated by WRF and MM5 by comparing the results with observations from Linate airport.

\subsubsection{Surface meteorology statistics}

The analysis of the annual averaged statistics shows that the temperatures are mainly underestimated, up to $3.6^{\circ} \mathrm{C}$ (for MM5 in Mantova), however WRF model gives higher temperatures than MM5, Table 3a. The RMSE is within the range of 2.3 to $4.3^{\circ} \mathrm{C}$ for both models. The values of relative humidity are in general overestimated by WRF and underestimated by MM5 but the differences between models 
Table 3a. Statistics for the temperature at the $2 \mathrm{~m}$ height.

\begin{tabular}{|c|c|c|c|c|c|c|c|c|c|c|c|c|}
\hline \multirow{2}{*}{\multicolumn{2}{|c|}{$\begin{array}{l}\text { Parameter/model } \\
\text { Time period/station }\end{array}$}} & \multicolumn{2}{|c|}{ BIAS $\left[{ }^{\circ} \mathrm{C}\right]$} & \multicolumn{2}{|c|}{$\operatorname{RMSE}\left[{ }^{\circ} \mathrm{C}\right]$} & \multicolumn{3}{|c|}{$\mathrm{SD}\left[{ }^{\circ} \mathrm{C}\right]$} & \multicolumn{2}{|c|}{ R squared } & \multirow{2}{*}{$\begin{array}{r}\text { NR } \\
\text { OBS }\end{array}$} & \multirow{2}{*}{$\begin{array}{r}\text { MEAN OBS } \\
{\left[{ }^{\circ} \mathrm{C}\right]}\end{array}$} \\
\hline & & WRF & MM5 & WRF & MM5 & OBS & WRF & MM5 & WRF & MM5 & & \\
\hline \multirow{6}{*}{ YEAR } & ISPRA & 0.4 & -2.4 & 3.1 & 3.9 & 8.8 & 8.0 & 8.4 & 0.9 & 0.9 & 7958 & 13.1 \\
\hline & ERBA & -1.2 & -1.7 & 3.6 & 3.7 & 8.9 & 8.1 & 7.9 & 0.9 & 0.9 & 6929 & 10.7 \\
\hline & CANTU & 0.5 & -0.4 & 3.1 & 2.9 & 9.6 & 8.6 & 8.6 & 0.9 & 0.9 & 8521 & 11.2 \\
\hline & SERMIDE & -1.2 & -1.5 & 2.3 & 2.5 & 9.0 & 9.4 & 9.1 & 1.0 & 1.0 & 8724 & 13.6 \\
\hline & MANTOVA & -3.2 & -3.6 & 3.9 & 4.3 & 9.8 & 9.5 & 9.1 & 1.0 & 1.0 & 8285 & 15.4 \\
\hline & ISPRA & 1.7 & -1.3 & 4.3 & 4.1 & 4.9 & 3.5 & 3.3 & 0.4 & 0.4 & 742 & 1.9 \\
\hline \multirow{4}{*}{ JANUARY } & ERBA & 0.7 & 0.3 & 3.0 & 3.1 & 4.1 & 3.7 & 3.6 & 0.5 & 0.4 & 742 & 2.2 \\
\hline & CANTU & 1.8 & 1.0 & 4.4 & 4.2 & 5.2 & 3.6 & 3.2 & 0.4 & 0.4 & 742 & 0.6 \\
\hline & SERMIDE & -0.7 & -1.2 & 2.0 & 2.3 & 2.6 & 2.5 & 2.5 & 0.5 & 0.5 & 742 & 2.2 \\
\hline & MANTOVA & -1.8 & -2.1 & 2.6 & 2.9 & 2.7 & 2.7 & 2.7 & 0.6 & 0.5 & 610 & 3.1 \\
\hline \multirow{5}{*}{ JUNE } & ISPRA & -0.4 & -2.2 & 3.3 & 3.8 & 5.8 & 4.0 & 4.8 & 0.7 & 0.7 & 720 & 21.6 \\
\hline & ERBA & -3.3 & -3.7 & 4.0 & 4.2 & 5.6 & 4.5 & 4.4 & 0.9 & 0.9 & 720 & 22.8 \\
\hline & CANTU & -0.3 & -0.8 & 2.4 & 2.2 & 5.9 & 4.7 & 4.9 & 0.9 & 0.9 & 648 & 21.2 \\
\hline & SERMIDE & -1.4 & -1.5 & 2.0 & 2.4 & 5.0 & 5.6 & 5.9 & 0.9 & 0.9 & 696 & 23.3 \\
\hline & MANTOVA & -4.0 & -4.5 & 4.4 & 4.9 & 5.8 & 5.5 & 5.5 & 0.9 & 0.9 & 720 & 26.1 \\
\hline
\end{tabular}

Table 3b. Statistics for the relative humidity at the $2 \mathrm{~m}$ height.

\begin{tabular}{|c|c|c|c|c|c|c|c|c|c|c|c|c|}
\hline \multirow{2}{*}{\multicolumn{2}{|c|}{$\begin{array}{l}\text { Parameter/model } \\
\text { Time period/station }\end{array}$}} & \multicolumn{2}{|c|}{ BIAS [\%] } & \multicolumn{2}{|c|}{ RMSE [\%] } & \multicolumn{3}{|c|}{$\mathrm{SD}[\%]$} & \multicolumn{2}{|c|}{ R squared } & \multirow{2}{*}{$\begin{array}{r}\text { NR } \\
\text { OBS }\end{array}$} & \multirow{2}{*}{$\begin{array}{r}\text { MEAN OBS } \\
{[\%]}\end{array}$} \\
\hline & & WRF & MM5 & WRF & MM5 & OBS & WRF & MM5 & WRF & MM5 & & \\
\hline \multirow{5}{*}{ YEAR } & ISPRA & -5 & -2 & 18 & 20 & 24 & 17 & 18 & 1 & 0 & 7957 & 73 \\
\hline & ERBA & 2 & -2 & 15 & 17 & 21 & 17 & 19 & 1 & 0 & 7001 & 64 \\
\hline & CANTU & 3 & -1 & 16 & 19 & 24 & 18 & 19 & 1 & 0 & 7758 & 68 \\
\hline & MANTOVA & 3 & 4 & 13 & 13 & 21 & 19 & 18 & 1 & 1 & 7215 & 67 \\
\hline & ISPRA & -10 & -10 & 26 & 31 & 28 & 21 & 21 & 0 & 0 & 742 & 76 \\
\hline \multirow{3}{*}{ JANUARY } & ERBA & -6 & -11 & 19 & 24 & 23 & 17 & 19 & 0 & 0 & 742 & 66 \\
\hline & CANTU & 1 & -6 & 18 & 23 & 26 & 20 & 22 & 1 & 0 & 407 & 67 \\
\hline & MANTOVA & -3 & -8 & 10 & 15 & 15 & 18 & 18 & 1 & 0 & 198 & 84 \\
\hline \multirow{4}{*}{ JUNE } & ISPRA & -6 & -3 & 17 & 16 & 23 & 13 & 15 & 1 & 1 & 720 & 71 \\
\hline & ERBA & 8 & 6 & 14 & 14 & 17 & 15 & 17 & 1 & 0 & 720 & 57 \\
\hline & CANTU & 11 & 7 & 17 & 16 & 19 & 15 & 17 & 1 & 0 & 720 & 56 \\
\hline & MANTOVA & 7 & 9 & 12 & 14 & 17 & 16 & 17 & 1 & 1 & 720 & 53 \\
\hline
\end{tabular}

and observations are comparable to the uncertainty of measurements (3-5\%), Table 3b. WRF output follows better the hourly pattern of relative humidity.

The results for wind speed and wind direction can be evaluated only for 2 monitoring sites i.e. Ispra and Mantova, Fig. 2a and Table 3c-d. Moreover, the wind data are largely missing for Mantova for the winter period (January-March) and for Ispra for the first half of the year. Therefore the reliable statistically analysis of the results is ensured mainly annually and for the summer period (in Mantova). The Po valley area is characterized by low wind speeds (stagnant conditions), which makes the wind field difficult to simulate with the prognostic meteorological models such as MM5 (Dosio et al., 2002; Baertsch-Ritter et al., 2003; Minguzzi et al. 2005; Carvalho et al., 2006; Stern et al., 2008). This has been confirmed also by the results described in this work. The wind speed is overestimated up to $1.7 \mathrm{~m} / \mathrm{s}$ (less by MM5). The prevailing annual wind direction is well reproduced by both models (especially for the Ispra location). The annual amount of rain is overestimated by WRF and in general underestimated by MM5, Fig. 2b. The analysis of the hit rate for precipitation events over the whole year 2005 was performed using 6 threshold values for the rain amount accumulated over the day: $0.1 \mathrm{~mm} /$ day, $0.2 \mathrm{~mm} /$ day, $0.5 \mathrm{~mm} /$ day, $1 \mathrm{~mm} /$ day, $2 \mathrm{~mm} /$ day and $5 \mathrm{~mm} /$ day (see Table $3 \mathrm{e}$ ). The hit rate statistics are in general better for WRF.

For the winter period WRF gives higher temperatures than MM5. The RMSE values for both models are also similar as for the annual means. The relative humidity is underestimated by both models, however more by MM5 (8-11\%). For both of these parameters WRF results show generally higher $\mathrm{R}$ squared values than MM5 results. 
Table 3c. Statistics for the wind speed.

\begin{tabular}{|c|c|c|c|c|c|c|c|c|c|c|c|c|}
\hline \multirow{2}{*}{\multicolumn{2}{|c|}{$\begin{array}{l}\text { Parameter/model } \\
\text { Time period/station }\end{array}$}} & \multicolumn{2}{|c|}{ BIAS [m/s] } & \multicolumn{2}{|c|}{$\mathrm{RMSE}[\mathrm{m} / \mathrm{s}]$} & \multicolumn{3}{|c|}{$\mathrm{SD}[\mathrm{m} / \mathrm{s}]$} & \multicolumn{2}{|c|}{ R squared } & \multirow{2}{*}{$\begin{array}{l}\text { NR } \\
\text { OBS }\end{array}$} & \multirow{2}{*}{$\begin{array}{l}\text { MEAN OBS } \\
{[\mathrm{m} / \mathrm{s}]}\end{array}$} \\
\hline & & WRF & MM5 & WRF & MM5 & OBS & WRF & MM5 & WRF & MM5 & & \\
\hline \multirow{2}{*}{ YEAR } & ISPRA & 1.7 & 1.0 & 2.4 & 1.5 & 0.8 & 2.3 & 1.7 & 0.0 & 0.0 & 8757 & 2.5 \\
\hline & MANTOVA & 2.2 & 2.0 & 2.8 & 2.6 & 0.3 & 1.8 & 1.7 & 0.2 & 0.1 & 6479 & 0.4 \\
\hline \multirow{2}{*}{ JANUARY } & ISPRA & - & - & - & - & - & 3.1 & 2.0 & - & - & - & - \\
\hline & MANTOVA & 2.2 & 2.7 & 2.7 & 3.3 & 0.2 & 1.7 & 1.8 & 0.0 & 0.0 & 127 & 0.4 \\
\hline \multirow{2}{*}{ JUNE } & ISPRA & - & - & - & - & - & 1.8 & 1.2 & 0.0 & - & - & - \\
\hline & MANTOVA & 2.2 & 1.8 & 2.7 & 2.2 & 0.2 & 1.7 & 1.3 & 0.1 & 0.1 & 719 & 0.5 \\
\hline
\end{tabular}

There was not enough data available to perform a robust comparison of the MM5 and WRF results on wind speed and direction with observations. The data for Mantova (only available for the first week of January 2005) show that the wind speed is largely overestimated by both models, however, BIAS and RMSE values are lower for WRF than for MM5. The MAE values calculated for wind direction data are comparable for both models (see Table $3 \mathrm{c}$ and d).

The WRF model overestimates the rainfall and shows in general more precipitation than MM5 for January 2005, Fig. 2b. The very high value of rain amount given by WRF for Sermide is caused mainly by the rainfall forecasted by WRF, which is $2.39 \mathrm{~cm}$ on 1 January, at hour 02:00 LST and then, about the same amount of rain between the 18 (17:00 LST) and 19 (09:00 LST) January. Observational data show the first rainfall on 5 January (hour 09:00) which is $0.02 \mathrm{~cm}$ and reach the amount of only $1 \mathrm{~cm}$ by the end of the month. WRF output calculates $5.82 \mathrm{~cm}$ of rain and MM5 about $2.6 \mathrm{~cm}$ of cumulated rainfall for January. The hit rate statistics were not analyzed for January, because there is not enough data in this period (to less and very small precipitation events).

In the summer period both models underestimate the temperature, up to $4.5^{\circ} \mathrm{C}$ (for MM5 in Mantova) and have similar $\mathrm{R}$ squared values, although WRF gives smaller error values. The relative humidity is mainly overestimated. WRF results show higher R squared values than MM5 but the BIAS values are generally lower for MM5 for this parameter. For the summer period the comparison between modelled and observed wind speed and wind direction was possible only for the monitoring station in Mantova. The wind speeds are overestimated by both models of about $2 \mathrm{~m} / \mathrm{s}$, although the error values are lower for MM5. The wind direction is poorly reproduced. The daily values of the hit rate statistics for June 2005 did not give enough observed occurrences of the events and the hit rate statistics are for that reason unsound. Therefore the analysis was done using 4 thresholds of the rain amount accumulated over $6 \mathrm{~h}: 0.1 \mathrm{~mm} / 6 \mathrm{~h}, 0.2 \mathrm{~mm} / 6 \mathrm{~h}$, $0.5 \mathrm{~mm} / 6 \mathrm{~h}, 1 \mathrm{~mm} / 6 \mathrm{~h}$ (see Table $3 \mathrm{f}$ ). WRF catches the precipitation events better than MM5. However, the amount of the rain is overestimated by both models for June 2005.
Table 3d. Statistics for the wind direction.

\begin{tabular}{llccc}
\hline \multicolumn{2}{c}{ Parameter/model } & \multicolumn{2}{c}{ MAE $\left[^{\circ}\right]$} & NR \\
Time period/station & & WRF & MM5 & OBS \\
\hline \multirow{2}{*}{ YEAR } & ISPRA & 93.1 & 77.6 & 8757 \\
\multirow{2}{*}{ JANUARY } & MANTOVA & 84.0 & 81.6 & 6479 \\
\multirow{2}{*}{ JUNE } & ISPRA & - & - & - \\
& MANTOVA & 76.7 & 77.5 & 127 \\
& ISPRA & - & - & - \\
& MANTOVA & 82.5 & 80.0 & 719 \\
\hline
\end{tabular}

\subsubsection{Sounding data statistics}

In this section we evaluate the vertical profile of the potential temperature gradient calculated by WRF and MM5 by comparing the results with observations from the Linate airport location.

In Fig. 3a-e we compare the potential temperature gradient (ptg) profile between $10 \mathrm{~m}$ and $200 \mathrm{~m}$ at the hours 00:00 h, 06:00 h, 12:00 $\mathrm{h}$ and 18:00 $\mathrm{h}$ for the whole year. Positive values in Fig. $3 \mathrm{a}$ indicate that the atmospheric layer between $10 \mathrm{~m}$ and $200 \mathrm{~m}$ is stable, negative values indicates that the layer is unstable, values around 0 indicates neutral conditions of the atmosphere (Stull, 1988). We see that the ptg profile by MM5 and WRF is in good agreement with the observations. At 00:00 h the ptg profile by MM5 is in general higher than by WRF. At 06:00 h the ptg profile by WRF and MM5 are similar and correspond well with the observations. At 12:00 h we see that from spring time (day 60) to autumn (day 280) the ptg profiles are negative, indicating unstable conditions in the first $200 \mathrm{~m}$. These instable conditions are well captured by both MM5 and WRF. During winter time both models calculate stable conditions, which corresponds to the observations. At $18.00 \mathrm{~h}$ we have limited observational data available. However, the ptg profile by WRF agrees well with the observations.

In Fig. 3b-e Taylor diagrams are shown (one per analyzed time) which integrate three statistical measures on one plot (Taylor, 2001). The black star represents observations and coloured stars - the models. Apart from the standard deviation and correlation coefficient, the diagram shows also the $\mathrm{RMSE}_{C}$ (centered RMSE), which is measured on the 
Table 3e. Hit rate statistics for the rain data, the whole of the year 2005 .

\begin{tabular}{|c|c|c|c|c|c|c|c|c|c|}
\hline & & \multicolumn{4}{|c|}{ WRF } & \multicolumn{4}{|c|}{ MM5 } \\
\hline & & ISPRA & ERBA & CANTU & SERMIDE & ISPRA & ERBA & CANTU & SERMIDE \\
\hline \multirow{5}{*}{$>0.1 \mathrm{~mm} /$ day } & POD & 0.67 & 0.75 & 0.73 & 0.70 & 0.62 & 0.74 & 0.71 & 0.79 \\
\hline & FA & 0.07 & 0.12 & 0.08 & 0.07 & 0.07 & 0.10 & 0.11 & 0.12 \\
\hline & FBI & 0.91 & 1.18 & 1.04 & 1.01 & 0.90 & 1.11 & 1.14 & 1.30 \\
\hline & HKS & 0.60 & 0.63 & 0.64 & 0.63 & 0.55 & 0.64 & 0.60 & 0.67 \\
\hline & OR & 28.47 & 22.18 & 29.28 & 29.10 & 20.89 & 24.90 & 19.33 & 27.50 \\
\hline \multirow{5}{*}{$>0.2 \mathrm{~mm} /$ day } & POD & 0.60 & 0.79 & 0.70 & 0.71 & 0.52 & 0.67 & 0.69 & 0.73 \\
\hline & FA & 0.05 & 0.10 & 0.07 & 0.06 & 0.07 & 0.09 & 0.08 & 0.08 \\
\hline & FBI & 0.85 & 1.28 & 1.03 & 1.06 & 0.87 & 1.11 & 1.05 & 1.20 \\
\hline & HKS & 0.55 & 0.68 & 0.63 & 0.65 & 0.45 & 0.58 & 0.61 & 0.64 \\
\hline & OR & 29.41 & 32.49 & 29.74 & 37.20 & 15.24 & 20.27 & 24.82 & 30.06 \\
\hline \multirow{5}{*}{$>0.5 \mathrm{~mm} /$ day } & POD & 0.60 & 0.70 & 0.58 & 0.59 & 0.54 & 0.50 & 0.58 & 0.53 \\
\hline & FA & 0.04 & 0.07 & 0.06 & 0.06 & 0.03 & 0.05 & 0.06 & 0.06 \\
\hline & FBI & 0.94 & 1.15 & 1.00 & 1.19 & 0.83 & 0.83 & 1.00 & 1.16 \\
\hline & HKS & 0.56 & 0.63 & 0.52 & 0.53 & 0.51 & 0.45 & 0.52 & 0.47 \\
\hline & OR & 35.38 & 31.24 & 20.99 & 23.00 & 33.84 & 19.53 & 20.99 & 16.89 \\
\hline \multirow{5}{*}{$>1 \mathrm{~mm} /$ day } & POD & 0.71 & 0.67 & 0.54 & 0.43 & 0.58 & 0.48 & 0.46 & 0.43 \\
\hline & FA & 0.02 & 0.05 & 0.04 & 0.04 & 0.01 & 0.02 & 0.03 & 0.04 \\
\hline & FBI & 0.92 & 1.26 & 1.00 & 1.10 & 0.67 & 0.74 & 0.77 & 1.00 \\
\hline & HKS & 0.69 & 0.62 & 0.50 & 0.39 & 0.58 & 0.46 & 0.44 & 0.39 \\
\hline & OR & 146.20 & 39.00 & 28.68 & 16.88 & 212.80 & 42.58 & 32.04 & 19.81 \\
\hline \multirow{5}{*}{$>2 \mathrm{~mm} / \mathrm{day}$} & POD & 0.83 & 0.46 & 0.73 & 0.20 & 0.67 & 0.46 & 0.27 & 0.40 \\
\hline & FA & 0.00 & 0.02 & 0.02 & 0.02 & 0.01 & 0.02 & 0.02 & 0.01 \\
\hline & FBI & 0.92 & 1.08 & 1.27 & 0.90 & 0.83 & 0.92 & 0.82 & 0.70 \\
\hline & HKS & 0.83 & 0.44 & 0.71 & 0.18 & 0.66 & 0.44 & 0.25 & 0.39 \\
\hline & OR & 1585.00 & 35.79 & 140.44 & 11.93 & 316.00 & 48.00 & 19.75 & 75.11 \\
\hline \multirow{5}{*}{$>5 \mathrm{~mm} / \mathrm{day}$} & POD & 0.00 & 0.67 & 1.00 & 0.00 & 0.00 & 0.00 & 0.00 & 0.00 \\
\hline & FA & 0.01 & 0.01 & 0.00 & 0.01 & 0.00 & 0.00 & 0.00 & 0.00 \\
\hline & FBI & 3.00 & 1.33 & 1.50 & 4.00 & 0.00 & 0.33 & 0.50 & 1.00 \\
\hline & HKS & -0.01 & 0.66 & 1.00 & -0.01 & 0.00 & 0.00 & 0.00 & 0.00 \\
\hline & OR & 0.00 & 350.00 & - & 0.00 & - & 0.00 & 0.00 & 0.00 \\
\hline
\end{tabular}

plot as the distance between the observed and modelled values. For the hour 00:00 and 06:00 WRF performs better than MM5 in the sense that its results give higher correlation values, standard deviation closer to the observed one and also the $\mathrm{RMSE}_{C}$ in this case is smaller than for MM5. At the hour 12:00 both models perform with similar quality, however MM5 shows the standard deviation which is closer to observed values. At the hour 18:00 MM5 also reproduces the observed standard deviation values better than WRF. However, WRF gives higher correlation value and lower $\mathrm{RMSE}_{C}$ than MM5 for this time. In general we can say that the potential temperature gradient by WRF is better than by MM5.

\subsection{Aerosols and ozone}

In this section the impact of using two different meteorological models, MM5 and WRF in the CHIMERE model, on calculated $\mathrm{PM}_{10}$ and $\mathrm{O}_{3}$ (ozone) concentrations is presented for January and June 2005.

\subsubsection{Calculated $\mathrm{PM}_{10}$ concentrations with MM5 and WRF meteorology for January 2005}

Aerosols formation is non-linear dependent on meteorological parameters, such as relative humidity, temperature, and removal processes (e.g. precipitation), which determine how aerosols are dispersed and transported over distance. Therefore for the comparison of calculated $\mathrm{PM}_{10}$ concentrations we selected those stations for which we have also meteorological data available. The combination of having $\mathrm{PM}_{10}$ measurement data together with meteorological data, allows us to understand better the $\mathrm{PM}_{10}$ profile.

For both simulations, using MM5 and WRF meteorology (CHIMERE/MM5 and CHIMERE/WRF), the model underestimates on average the observed $\mathrm{PM}_{10}$ concentrations for the five stations by a factor 2 and 3.2 for January respectively, see Table 4. Analyzing the calculated $\mathrm{PM}_{10}$ concentrations for the stations, we find that CHIMERE/MM5 
Table 3f. Hit rate statistics for the rain data, June 2005.

\begin{tabular}{|c|c|c|c|c|c|c|c|c|c|}
\hline & & \multicolumn{4}{|c|}{ WRF } & \multicolumn{4}{|c|}{ MM5 } \\
\hline & & ISPRA & ERBA & CANTU & SERMIDE & ISPRA & ERBA & CANTU & SERMIDE \\
\hline \multirow{5}{*}{$>0.1 \mathrm{~mm} / 6 \mathrm{~h}$} & POD & 0.40 & 0.56 & 0.63 & 0.33 & 0.70 & 0.56 & 0.63 & 0.33 \\
\hline & FA & 0.05 & 0.07 & 0.05 & 0.03 & 0.05 & 0.15 & 0.15 & 0.06 \\
\hline & FBI & 0.90 & 1.44 & 1.25 & 1.33 & 1.30 & 2.44 & 2.38 & 2.67 \\
\hline & HKS & 0.35 & 0.48 & 0.57 & 0.31 & 0.65 & 0.40 & 0.48 & 0.27 \\
\hline & OR & 14.00 & 16.09 & 30.33 & 17.50 & 40.44 & 6.91 & 9.76 & 7.21 \\
\hline \multirow{5}{*}{$>0.2 \mathrm{~mm} / 6 \mathrm{~h}$} & POD & 0.43 & 0.57 & 0.57 & 0.00 & 0.43 & 0.43 & 0.57 & 0.00 \\
\hline & FA & 0.04 & 0.06 & 0.03 & 0.03 & 0.05 & 0.10 & 0.08 & 0.03 \\
\hline & FBI & 1.00 & 1.57 & 1.00 & 1.50 & 1.29 & 2.00 & 1.71 & 1.50 \\
\hline & HKS & 0.39 & 0.51 & 0.54 & -0.03 & 0.38 & 0.33 & 0.49 & -0.03 \\
\hline & OR & 20.44 & 20.19 & 41.78 & 0.00 & 13.38 & 6.95 & 14.83 & 0.00 \\
\hline \multirow{5}{*}{$>0.5 \mathrm{~mm} / 6 \mathrm{~h}$} & POD & 0.40 & 0.67 & 0.50 & 0.00 & 0.40 & 0.33 & 0.25 & 0.00 \\
\hline & FA & 0.02 & 0.03 & 0.02 & 0.02 & 0.01 & 0.03 & 0.06 & 0.00 \\
\hline & FBI & 0.80 & 2.00 & 1.00 & 2.00 & 0.60 & 1.33 & 1.75 & 0.00 \\
\hline & HKS & 0.38 & 0.63 & 0.48 & -0.02 & 0.39 & 0.31 & 0.19 & 0.00 \\
\hline & OR & 37.67 & 56.00 & 49.00 & 0.00 & 76.00 & 18.83 & 5.22 & - \\
\hline \multirow{5}{*}{$>1 \mathrm{~mm} / 6 \mathrm{~h}$} & POD & 0.00 & 1.00 & 0.50 & - & 0.50 & 1.00 & 0.50 & - \\
\hline & FA & 0.02 & 0.03 & 0.02 & 0.02 & 0.00 & 0.02 & 0.02 & 0.00 \\
\hline & FBI & 1.00 & 4.00 & 1.50 & - & 0.50 & 3.00 & 1.50 & - \\
\hline & HKS & -0.02 & 0.97 & 0.48 & - & 0.50 & 0.98 & 0.48 & - \\
\hline & OR & 0.00 & - & 50.00 & - & - & - & 50.00 & - \\
\hline
\end{tabular}

shows an underestimation in $\mathrm{PM}_{10}$ for the Ispra station by a factor 1.3. Very high $\mathrm{PM}_{10}$ concentrations are observed at the beginning of the month for Mantova, leading to a monthly mean measured value of $207 \mu \mathrm{g} / \mathrm{m}^{3}$, resulting to an underestimation of the model by a factor 3 (CHIMERE/MM5) and 6 (CHIMERE/WRF) for this station. These values are caused by fireworks at the beginning of the month (ARPA Lombardy, personal communication). Emissions from fireworks are not included in our emission inventory. However, from the second half of the week onwards for Mantova, we find that the model underestimates $\mathrm{PM}_{10}$ by a factor 1.1 to 2.1 for both the simulations (CHIMERE/MM5 and CHIMERE/WRF). Excluding Mantova form the analysis shows a significant improvement of the results. $\mathrm{PM}_{10}$ concentrations are for the four stations underestimated on average by a factor 1.4 (CHIMERE/MM5) and 2 (CHIMERE/WRF).

As shown above, differences in calculated and observed $\mathrm{PM}_{10}$ concentrations are also found for the EMEP measurement station at Ispra (I). For this station we have to our disposal surface concentrations of $\mathrm{SO}_{4}^{=}, \mathrm{NO}_{3}^{-}, \mathrm{NH}_{4}^{+}$, organic carbon and black carbon, which allows us to compare these aerosol species with model calculated values and allows us to determine which of the aerosol species is responsible for the discrepancy between observed and calculated aerosol concentrations.

Comparing $\mathrm{NO}_{3}^{-}$aerosol $\left(9.31 \mu \mathrm{g} / \mathrm{m}^{3}\right)$ and $\mathrm{NH}_{4}^{+}$ $\left(4.21 \mu \mathrm{g} / \mathrm{m}^{3}\right)$ for Ispra, we found that CHIMERE/WRF is in good agreement with the observations, see Table 5.
CHIMERE/MM5 overestimates the observed $\mathrm{NO}_{3}^{-}$ aerosol concentrations by a factor of 1.4 , while $\mathrm{NH}_{4}^{+}$ calculated concentrations are in good agreement with the observations. The latter could be related to the underestimation by the model of $\mathrm{SO}_{4}^{=}$and overestimation of $\mathrm{NO}_{3}^{-}$. The temporal correlation coefficients by CHIMERE/WRF are higher than by CHIMERE/MM5. $\mathrm{SO}_{4}^{=}$is underestimated by a factor 2 (CHIMERE/MM5) and 1.5 (CHIMERE/WRF) when compared to the monthly mean observed value $\left(3.83 \mu \mathrm{g} / \mathrm{m}^{3}\right)$. Calculated $\mathrm{SO}_{2}$ concentrations are in general overestimated by a factor 1.3 when compared to the measurements. The wintertime underestimation of sulphate concentrations has been reported by previous studies and is possibly due to the insufficient of oxidation chemistry in the model (Jeuken, 2000; Kasibhatla et al., 1997).

The large underestimation of $\mathrm{PM}_{10}$ could be related to the underestimation of black carbon and organic carbon. Our model gives the sum of organic carbon (OC), elemental carbon (EC) and anthropogenic dust. Analysing the sum of OC, EC and anthropogenic dust, denoted as PPM, we see that the model underestimates for January the measured PPM by a factor of around 3 and 4 for CHIMERE/MM5 and CHIMERE/WRF respectively, see Table 5. A possible explanation for this large underestimation is related to the frequent wood burning for heating purposes in northern Italy in winter time and the secondary organic aerosol formation, which can contribute to around $55 \%$ of the organic aerosol mass in winter time (Lanz et al., 2007). Uncertainties in the emission factors for EC and OC in the emission inventory 
Table 3f. Continued.

Definition of the statistical parameters used for the comparison between modelled and observed values.

$S D=\sqrt{\frac{\sum_{i=1}^{n}(y-\bar{y})^{2}}{n}}$

Standard deviation: a measure of the dispersion of the observed (calculated) values around the mean.

$\mathrm{RMSE}=\sqrt{\frac{\sum_{i=1}^{n}(x-y)^{2}}{n}}$

Root mean square error: a measure of difference between the model and the observations (measure of accuracy).

$\mathrm{BIAS}=\frac{\sum_{i=1}^{n} x-y}{n}$

$R^{2}=(\mathrm{CORR})^{2}$

Square of the correlation coefficient (indicates the linear relationship between model and observations).

$\mathrm{MAE}=\frac{\sum_{i=1}^{n} \mathrm{DWD}}{n}$,

where DWD - difference of the wind direction calculated from:

$\min (x-y, y-x+360)$, for $x>y$

$\mathrm{DWD}=\min (y-x, x-y+360)$, for $y>x$

Mean absolute error calculated to indicate the error in wind direction prediction.

$y$ - observed value

$\bar{y}$ - mean of observed values

$x$ - modelled value

$n$ - number of observations

Rain specific hit rate statistics:

For the hit rate statistics the following symbolic representation was used:

\begin{tabular}{cccc}
\hline & & \multicolumn{2}{c}{ Observation } \\
\hline \multirow{4}{*}{ Forecast } & Yes & No \\
& Yes & A & B \\
& No & C & D \\
\hline
\end{tabular}

A - correct hits,

B - false hits (false alarm),

$\mathrm{C}$ - false rejections (misses),

$\mathrm{D}$ - correct rejections.

including unaccounted sources, which contribute to the underestimation of EC and OC in the inventory could be held responsible for the underestimation of $\mathrm{PM}_{10}$ in a winter pe-
Table 3f. Continued.

Based on this the following categorical statistics were calculated:

$\mathrm{POD}=\frac{A}{A+C}$,

probability of detection of the rain event;

$F A=\frac{B}{B+D}$,

false alarm (probability of false detection of the rain event);

$\mathrm{FBI}=\frac{A+C}{A+B}$,

frequency BIAS (the measure of over - or underestimation of the events number; $\mathrm{FBI}=1$ indicates that the event is forecasted exactly as often as it is observed);

$\mathrm{HKS}=\frac{A D-B C}{(A+C)(B+D)}$,

Hansen-Kuipers score (indicates the ability of the model to give correct forecast of the event as well as to avoid the false alarms);

$O R=\frac{A D}{B C}$,

odds ratio $(\mathrm{OR}>1$ indicates that the $\mathrm{POD}>\mathrm{FA}$ ), (Stephenson, 2000; Goeber and Milton, 2001).

riod, as discussed by Schaap et al. (2004b). Another source for the underestimation can be related to the additional processes of SOA formation from traffic and wood burning as described in Robinson (2007), which are not included in our SOA formation scheme. Observations show that organic carbon has a significant contribution to the $\mathrm{PM}_{10}$ mass for Ispra (46\%), with $29.8 \mu \mathrm{g} / \mathrm{m}^{3}$. Elemental carbon contributes with $10 \%$ to $\mathrm{PM}_{10}$ mass $\left(5.1 \mu \mathrm{g} / \mathrm{m}^{3}\right)$, and dust contributes with $2.5 \%$ to the total $\mathrm{PM}_{10}$ mass $\left(1.4 \mu \mathrm{g} / \mathrm{m}^{3}\right)$.

\subsubsection{Differences in calculated $\mathbf{P M}_{10}$ concentrations between CHIMERE/MM5 and CHIMERE/WRF for January}

Our analysis of calculated $\mathrm{PM}_{10}$ concentrations for the five stations in January shows that modelled mean $\mathrm{PM}_{10}$ values between CHIMERE/MM5 and CHIMERE/WRF are different. The calculated $\mathrm{PM}_{10}$ values for CHIMERE/MM5 are on average a factor 1.6 higher than CHIMERE/WRF. Analyzing the monthly mean $\mathrm{PM}_{10}$ concentration for January for Ispra (CHIMERE/MM5), we find a concentration around $43.2 \mu \mathrm{g} / \mathrm{m}^{3}$. CHIMERE/WRF calculates a monthly mean $\mathrm{PM}_{10}$ concentration of $26.6 \mu \mathrm{g} / \mathrm{m}^{3}$ for Ispra, see Table 4. The temporal correlation coefficients by CHIMERE/WRF are higher than by CHIMERE/MM5, indicating that the spatial gradients of the daily mean concentrations are relatively well reproduced by the model using the WRF meteorology. 
Table 4. Monthly mean $\mathrm{PM}_{10}$ concentrations calculated by the CHIMERE model using MM5 and WRF meteorology for January 2005, including the standard deviation and the temporal correlation coefficient, together with the measurements.

\begin{tabular}{llll}
\hline Name station & $\begin{array}{l}\text { Monthly mean January model with } \\
\text { MM5 } \mu \mathrm{g} / \mathrm{m}^{3} \pm \mathrm{stdev} ; \\
\text { coeff. }\end{array}$ & $\begin{array}{l}\text { Monthly mean January model with } \\
\text { WRF } \mu \mathrm{g} / \mathrm{m}^{3} \pm \text { stdev.; } \\
\text { coeff. }\end{array}$ & $\begin{array}{l}\text { Monthly mean January obser- } \\
\text { vations } \mu \mathrm{g} / \mathrm{m}^{3} \pm \mathrm{stdev} .\end{array}$ \\
\hline Ispra & $43.2 \pm 22.3 ; 0.55$ & $26.9 \pm 13.3 ; 0.73$ & $57.4 \pm 31.7$ \\
Cantu & $43.7 \pm 21.3 ; 0.40$ & $28.7 \pm 15.9 ; 0.74$ & $78.8 \pm 40.6$ \\
Erba & $39.5 \pm 19.9 ; 0.42$ & $29.0 \pm 13.9 ; 0.70$ & $67.5 \pm 20.8$ \\
Mantova & $64.2 \pm 42.3 ; 0.70$ & $36.7 \pm 16.3 ; 0.82$ & $70.7 \pm 20.8$ \\
Castelnovo Bariano & $51.9 \pm 40.1 ; 0.27$ & $28.6 \pm 13.2 ; 0.47$ & 96.3 \\
Average & 48.5 & 30.0 & 207 \\
\hline
\end{tabular}

Table 5. Monthly mean measured concentrations for Ispra of $\mathrm{SO}_{4}^{=}, \mathrm{NO}_{3}^{-}$and $\mathrm{NH}_{4}^{+}$, together with the model calculated mean concentrations using MM5 and WRF, for January 2005, including the standard deviation and the temporal correlation coefficient.

\begin{tabular}{llll}
\hline Mean January 2005, Ispra & $\begin{array}{l}\text { EMEP measurement } \\
\mu \mathrm{g} / \mathrm{m}^{3} \pm \text { stdev. }\end{array}$ & $\begin{array}{l}\text { CHIMERE MM5 } \\
\mu \mathrm{g} / \mathrm{m}^{3} \pm \text { stdev.; } \\
\text { correlation coeff. }\end{array}$ & $\begin{array}{l}\text { CHIMERE WRF } \\
\mu \mathrm{g} / \mathrm{m}^{3} \pm \text { stdev.; } \\
\text { correlation coeff. }\end{array}$ \\
\hline $\mathrm{SO}_{4}^{-}$ & $3.83 \pm 3.20$ & $1.93 \pm 0.62 ; 0.20$ & $2.57 \pm 1.78 ; 0.77$ \\
$\mathrm{NO}_{3}^{-}$ & $9.31 \pm 8.84$ & $13.4 \pm 9.94 ; 0.69$ & $7.88 \pm 5.55 ; 0.84$ \\
$\mathrm{NH}_{4}^{+}$ & $4.21 \pm 3.93$ & $4.43 \pm 2.85 ; 0.70$ & $3.23 \pm 2.25 ; 0.88$ \\
Sum EC,OC, dust & $36.3 \pm 20.1$ & $12.9 \pm 9.68 ; 0.49$ & $8.23 \pm 6.06 ; 0.58$ \\
\hline
\end{tabular}

In general, the standard deviations by CHIMERE/MM5 are larger than by CHIMERE/WRF. The reason for this is that for CHIMERE/MM5 higher $\mathrm{PM}_{10}$ peak values are calculated than by CHIMERE/WRF.

The differences in $\mathrm{PM}_{10}$ concentrations for January are on average around $10 \mu \mathrm{g} / \mathrm{m}^{3}$ (not shown), with the exception of the period 14-18 January, where a large difference in calculated $\mathrm{PM}_{10}$ between the two simulations is found, see Sect. 4.2.3 for a detailed the explanation.

To understand the differences in $\mathrm{PM}_{10}$ between CHIMERE/MM5 and CHIMERE/WRF, we analyse the PBL heights and the related sensible and latent heat fluxes (SHF and LHF respectively) for the five different locations, for which we compare the $\mathrm{PM}_{10}$ calculated concentrations. The sensible heat flux (dry) and latent heat flux (moist) are provided by the land surface model. The reason why we analyze first the SHF and LHF is that these parameters provide the heat fluxes to the PBL scheme which stimulates the turbulence in the boundary layer and determines the height and temporal profile of the PBL and the resulting vertical aerosol distribution.

The LSM model applied in MM5 and WRF is Noah, therefore sensible and latent surface heat fluxes should be similar.

For the five different locations we observe similar SHF. On average the monthly mean SHF with MM5 is $-8.0 \mathrm{~W} / \mathrm{m}^{2}$ and with WRF $-6.9 \mathrm{~W} / \mathrm{m}^{2}$. However, for the LHF larger differences are observed between MM5 and WRF, which is in general $10.2 \mathrm{~W} / \mathrm{m}^{2}$ for $\mathrm{WRF}$ and $5.7 \mathrm{~W} / \mathrm{m}^{2}$ for MM5.
The underlying reason for these differences in LHF, is that the shortwave incoming radiation at the surface between MM5 and WRF is different. Overall more shortwave incoming radiation is estimated by MM5. On average the amount of shortwave incoming radiation for the five stations, between 07:00 LT-16:00 LT, is $124 \mathrm{~W} / \mathrm{m}^{2}$ for MM5 and for $116 \mathrm{~W} / \mathrm{m}^{2}$ for WRF. The downward shortwave radiation is a source of energy for the soil. More incoming shortwave radiation and the availability of moisture at the surface will stimulate the heat and moisture transport away upward from the surface (Stull, 1988). The difference in shortwave radiation between MM5 and WRF is a result of the difference in cloud cover. The cloud cover is diagnosed with the preprocessor in CHIMERE, which allows us to determine cloud cover and compare the amount of cloud liquid water between the two meteorological models.

Analyzing the cloud attenuation between the two meteorological models, we observe that in general MM5 shows less cloud attenuation than WRF does, which results in more incoming radiation by MM5. This is due to the difference in microphysics scheme. The number of hydrometer categories in WSM6 (vapour, cloud water, cloud ice, rain, snow, graupel) is larger than in the Simple Ice scheme (vapour, cloud water/ice, rain/snow), this leads to more cloud liquid water and more rain fall (Hong et al., 2006).

More cloud liquid water content by WRF, result in more cloud attenuation by WRF (and more rain by WRF as described in Sect. 4.1.1). This has an impact on the latent heat 

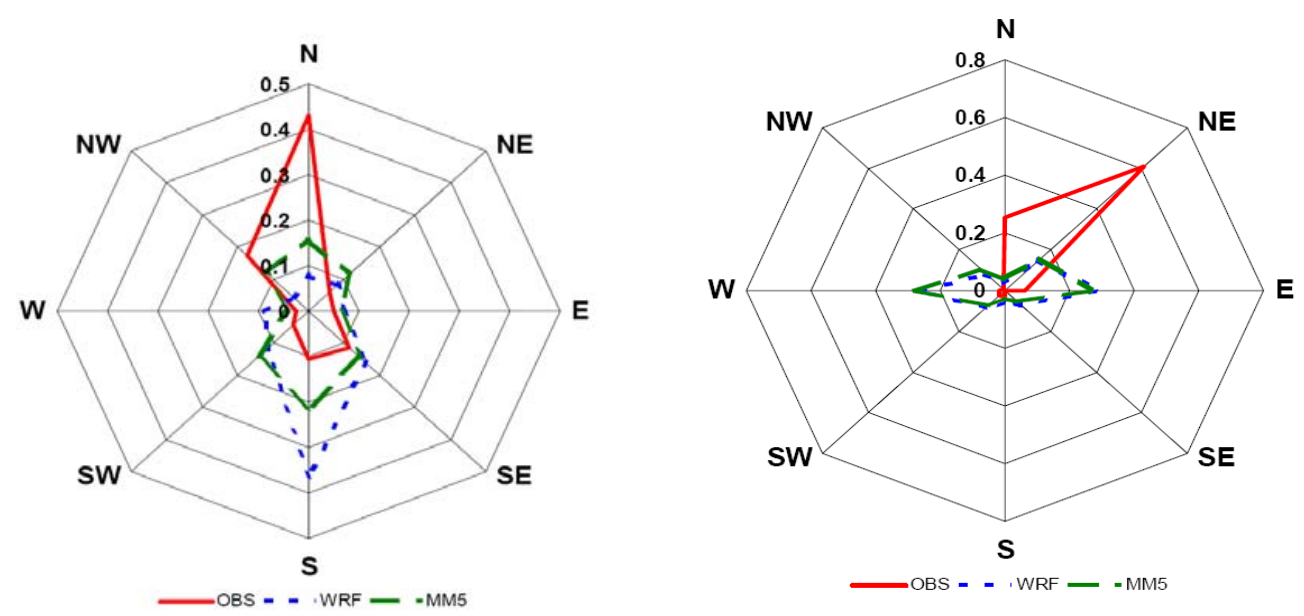

Fig. 2a. Wind roses for Ispra (left) and Mantova (right) monitoring stations, for the whole of the year 2005. The scale indicates the frequency of the wind direction.
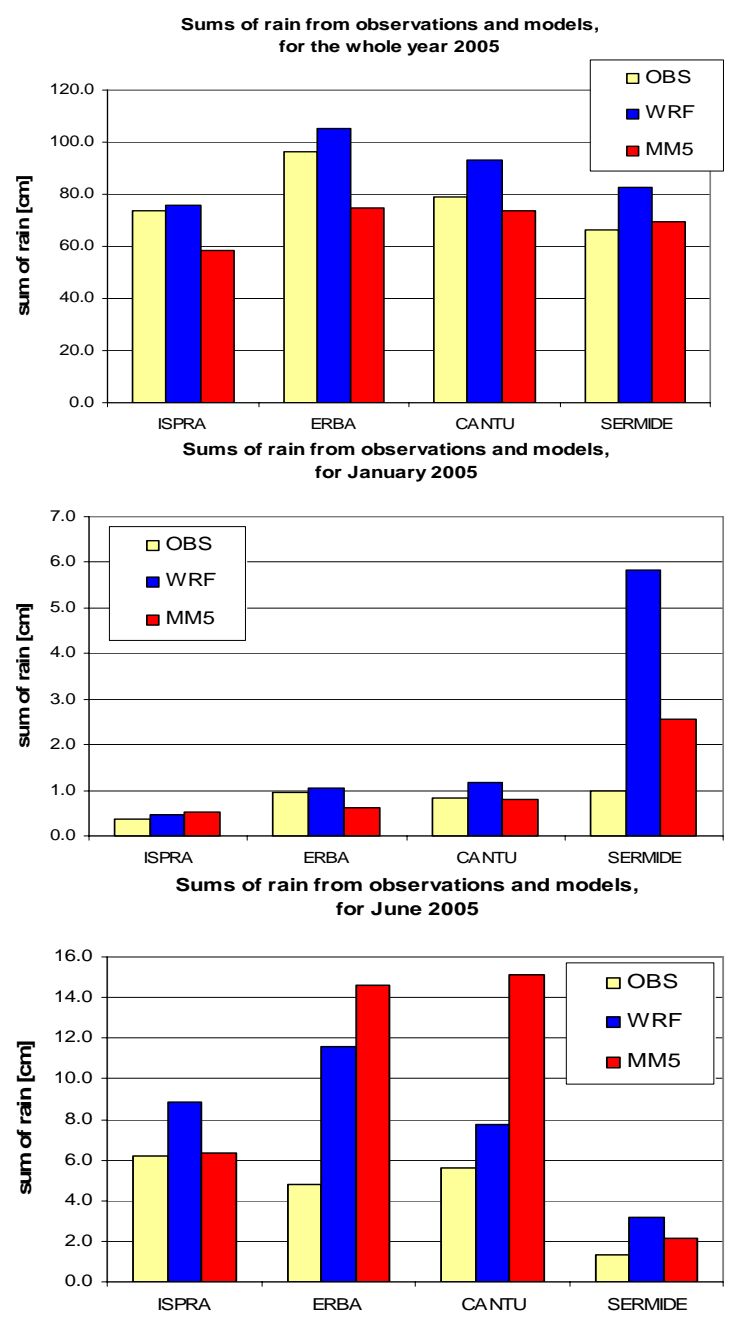

Fig. 2b. The quantities of rain observed and predicted by the models, respectively from top to bottom: for the whole of the year 2005, for January and for June. flux by WRF, which is in general almost a factor 2 higher as mentioned earlier. The difference in CLW between WRF and MM5 for the five stations is on average around a factor 1.2, up to a maximum of 4 (WRF higher). For some days the differences in CLW between WRF and MM5 are larger, because for some days MM5 does not calculate CLW while WRF does (see Sect. 4.2.3 for more details of this difference and the impact on the aerosol calculations).

This larger flux of latent heat by WRF is responsible for the higher PBL heights.

Another reason for the lower PBL heights by MM5 could be related to a stronger inversion effect by MM5. The temperatures at $2 \mathrm{~m}$ level for the five stations by MM5 are lower (bias $-3.3^{\circ} \mathrm{C}$ ) than by WRF (bias $1.7^{\circ} \mathrm{C}$ ) when compared to the observations, which indicate a stronger inversion effect by MM5 than by WRF. Analyzing the vertical temperature gradient profiles for the five stations for MM5 and WRF, we see indeed that MM5 has a stronger inversion gradient $\left(2.2^{\circ} \mathrm{C}\right)$ than $\mathrm{WRF}\left(0.7^{\circ} \mathrm{C}\right)$ over the first $150 \mathrm{~m}$.

On average, the PBL height by WRF for the five stations at noon is around $270 \mathrm{~m}$, while by MM5 $97 \mathrm{~m}$. This is more than a factor 2.8 difference. This difference in PBL height is responsible for the differences in aerosol concentrations between CHIMERE/WRF and CHIMERE/MM5. The vertical mixing with WRF meteorology is better, because of the higher PBL height, which leads to lower aerosol concentrations at ground level than with MM5 meteorology as mentioned before. 

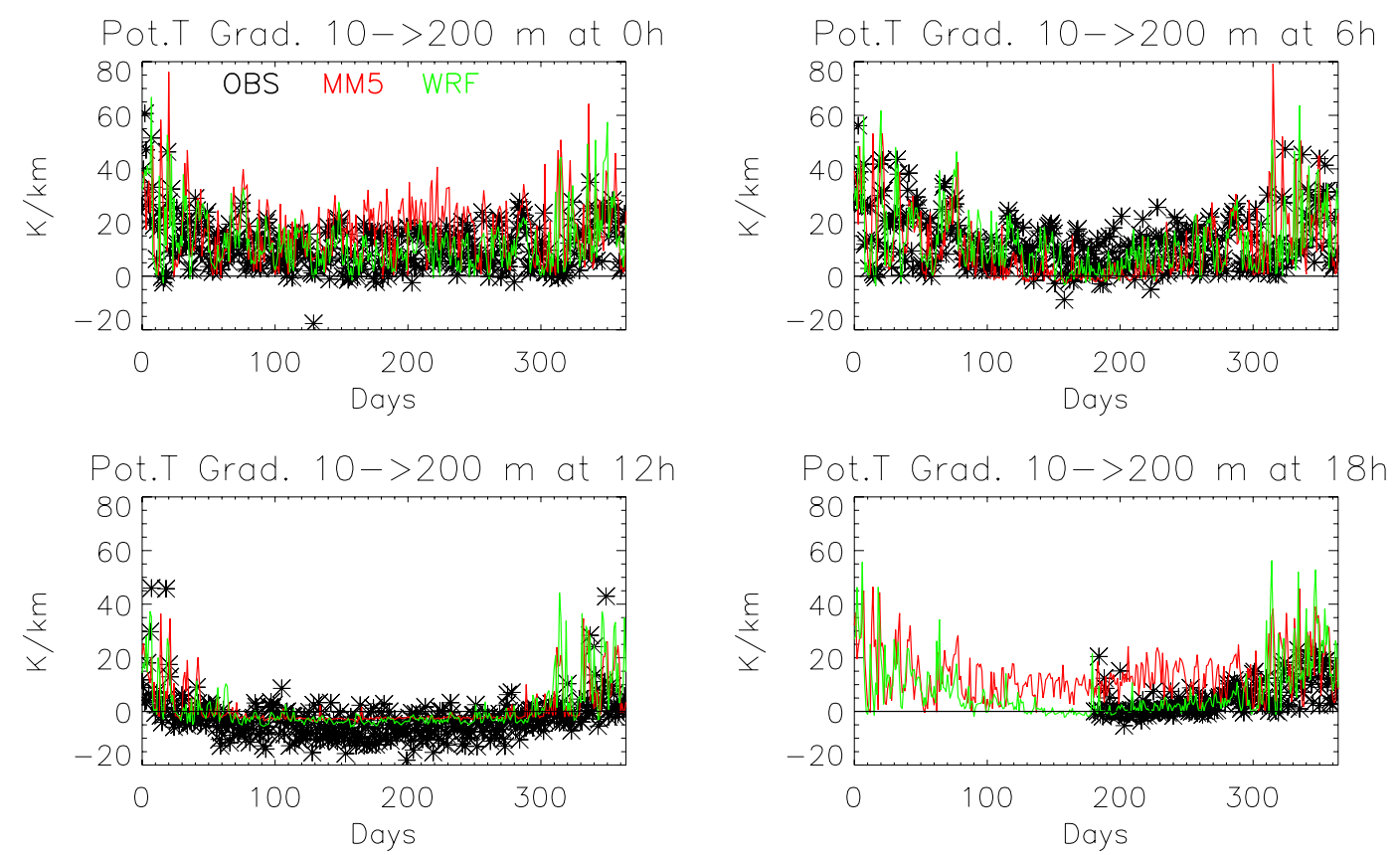

Fig. 3a. Vertical potential temperature gradient profiles between $10 \mathrm{~m}-200 \mathrm{~m}$ by WRF, MM5 for the Linate airport, together with the observations for 00:00 h, 06:00 h, 12:00 h and 18:00 $\mathrm{h}$ for the whole year.

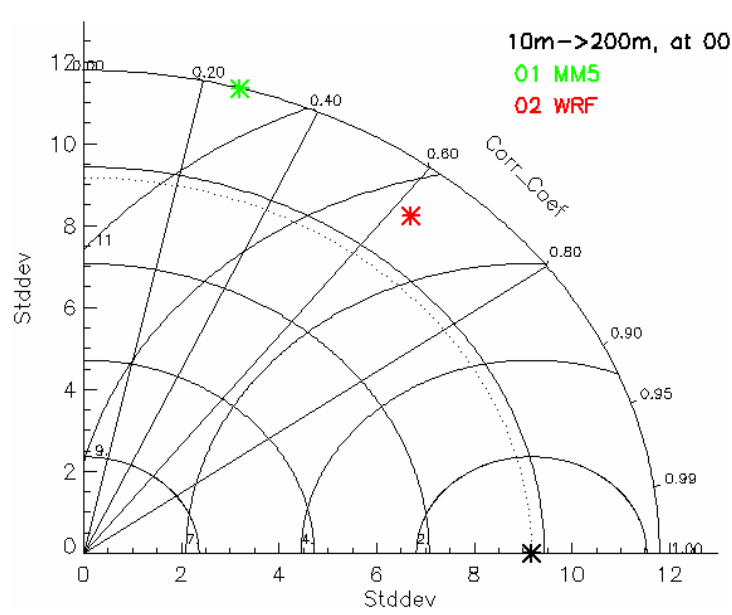

Fig. 3b. Statistics (Taylor plot, Taylor, 2001) for vertical potential temperature gradient profiles ( $10 \mathrm{~m}-200 \mathrm{~m})$ by WRF, MM5 for the Linate airport, together with the observations for 00:00 h for the whole year.

\subsubsection{Episode of large difference in $\mathrm{PM}_{10}$ concentrations between CHIMERE/MM5 and CHIMERE/WRF}

In Sect. 4.2.2 is mentioned that a large difference in calculated $\mathrm{PM}_{10}$ concentrations between CHIMERE/MM5 and CHIMERE/WRF is observed for the period 14-18 January for Ispra. In this section we give the explanation for this large difference in $\mathrm{PM}_{10}$.

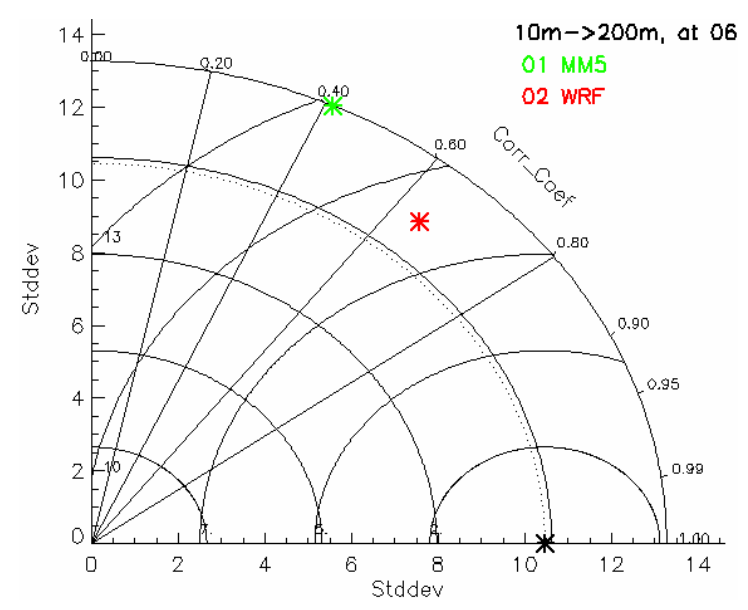

Fig. 3c. Statistics (Taylor plot, Taylor, 2001) for vertical potential temperature gradient profiles $(10 \mathrm{~m}-200 \mathrm{~m})$ by WRF, MM5 for the Linate airport, together with the observations for $06: 00 \mathrm{~h}$ for the whole year.

Analyzing the temporal profile of $\mathrm{PM}_{10}$ concentrations for January for CHIMERE/MM5 and CHIMERE/WRF, we observe maximum $\mathrm{PM}_{10}$ values of $90 \mu \mathrm{g} / \mathrm{m}^{3}$ by CHIMERE/MM5, whereas CHIMERE/WRF calculates a maximum of $45 \mu \mathrm{g} / \mathrm{m}^{3}$. This large difference in calculated $\mathrm{PM}_{10}$ concentrations cannot be explained by the difference in PBL scheme alone. 


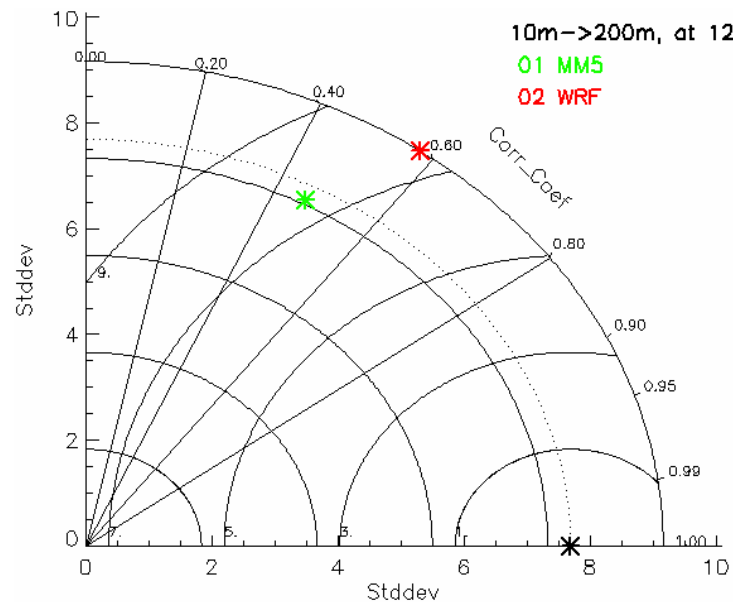

Fig. 3d. Statistics (Taylor plot, Taylor, 2001) for vertical potential temperature gradient profiles ( $10 \mathrm{~m}-200 \mathrm{~m})$ by WRF, MM5 for the Linate airport, together with the observations for 12:00 h for the whole year.

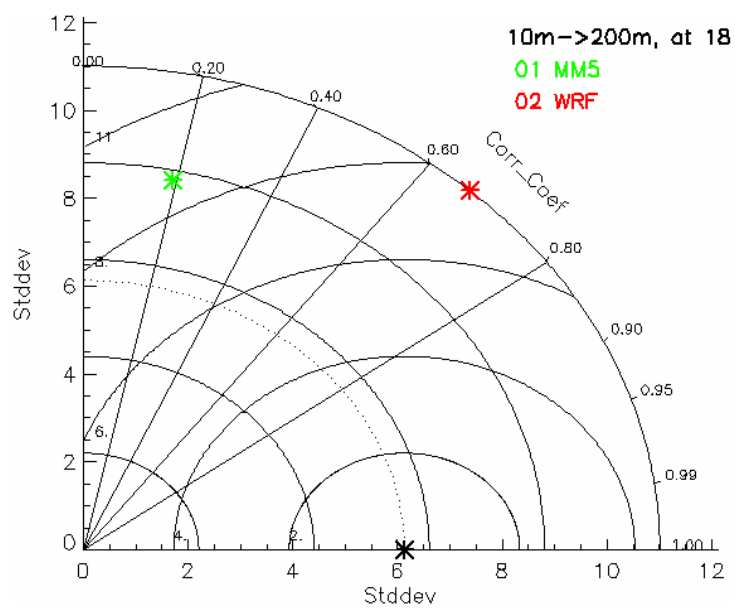

Fig. 3e. Statistics (Taylor plot, Taylor, 2001) for vertical potential temperature gradient profiles ( $10 \mathrm{~m}-200 \mathrm{~m})$ by WRF, MM5 for the Linate airport, together with the observations for 18:00 h for the whole year.

This large difference in $\mathrm{PM}_{10}$ calculated values is related to the difference in calculated $\mathrm{NO}_{3}^{-}$concentrations by CHIMERE/MM5 $\left(33 \mu \mathrm{g} / \mathrm{m}^{3}\right)$ and CHIMERE/WRF $\left(16 \mu \mathrm{g} / \mathrm{m}^{3}\right)$ for this period. The underlying reason for the higher $\mathrm{NO}_{3}^{-}$aerosol concentrations by CHIMERE/MM5 can be explained by the absence of cloud liquid water (CLW) in MM5 for that period (observed in WRF). As described before (Sect. 4.2.2) the microphysics scheme in WRF produces more CLW than in the Simple Ice scheme, because of the number of hydrometer categories in WSM6 (Hong et al., 2006). The oxidation of $\mathrm{SO}_{2}$ in cloud liquid water by $\mathrm{H}_{2} \mathrm{O}_{2}$ is very fast and is an important source of sulphate aerosol formation (Pandis and Seinfeld, 1989; Seinfeld and Pandis, and references herein), see reactions below:

$$
\begin{aligned}
& \mathrm{HSO}_{3}^{-}+\mathrm{H}_{2} \mathrm{O}_{2} \rightarrow \mathrm{SO}_{2} \mathrm{OOH}^{-}+\mathrm{H}_{2} \mathrm{O} \\
& \mathrm{SO}_{2} \mathrm{OOH}^{-}+\mathrm{H}^{+} \rightarrow \mathrm{H}_{2} \mathrm{SO}_{4}
\end{aligned}
$$

$\mathrm{SO}_{2}$ concentrations during this period with CHIMERE/WRF drop to an average of $0.75 \mathrm{ppb}$ while CHIMERE/MM5 calculates an average of $5.0 \mathrm{ppb}$ during this period. Mean $\mathrm{H}_{2} \mathrm{O}_{2}$ concentration for the CHIMERE/WRF is around $0.02 \mathrm{ppb}$, whereas CHIMERE/MM5 a mean of $0.07 \mathrm{ppb}$ is calculated for that period. CHIMERE/WRF calculates a mean concentration of $\mathrm{SO}_{4}^{=}$of $5.5 \mu \mathrm{g} / \mathrm{m}^{3}$, while CHIMERE/MM5 calculates a mean of $2.0 \mu \mathrm{g} / \mathrm{m}^{3} \mathrm{SO}_{4}^{=}$for that 5 days period. Measurements show an average of $9.3 \mu \mathrm{g} / \mathrm{m}^{3}$ for $\mathrm{SO}_{4}^{=}$for that period, with a maximum of $12.5 \mu \mathrm{g} / \mathrm{m}^{3}$ on 17 January. Observations show that clouds were present for that period (http: //iamest.jrc.it/meteo/meteo.php?). CHIMERE/MM5 calculates lower $\mathrm{SO}_{4}^{=}$concentration, because $\mathrm{SO}_{2}$ is not oxidized by $\mathrm{H}_{2} \mathrm{O}_{2}$ into $\mathrm{SO}_{4}^{=}$as there is no CLW observed by MM5 for that period. Due to the presence of CLW in the WRF meteorology, $\mathrm{SO}_{2}$ is oxidized by $\mathrm{H}_{2} \mathrm{O}_{2}$ into $\mathrm{SO}_{4}$ aerosol.

As mentioned before, CHIMERE/WRF calculates a mean $\mathrm{NO}_{3}^{-}$concentration of $16 \mu \mathrm{g} / \mathrm{m}^{3}$ for the period $14-18 \mathrm{th}$, whereas for CHIMERE/MM5 a mean concentration of $33 \mu \mathrm{g} / \mathrm{m}^{3}$ is calculated. These large differences in $\mathrm{NO}_{3}^{-}$ aerosol contribute to the differences in $\mathrm{PM}_{10}$.

The difference between the two simulations in $\mathrm{NO}_{3}^{-}$calculations can be explained by the reaction of the sulphate aerosol with ammonia. If sufficient ammonia is available to neutralize all sulphate, the residual amount of ammonia can neutralize nitric acid to form the ammonium nitrate aerosol. We have seen that CHIMERE/MM5 does not produce much $\mathrm{SO}_{4}^{=}$as CHIMERE/WRF does. This means that the ammonia can react with the nitric acid to form the nitrate aerosol, leading to a higher $\mathrm{NO}_{3}^{-}$concentration than CHIMERE/WRF, causing higher $\mathrm{PM}_{10}$ values between 14 and 18 January than CHIMERE/WRF. On days when no CLW is found for both MM5 and WRF, the difference in calculated aerosol concentrations between CHIMERE/MM5 and CHIMERE/WRF are smaller, around $10 \mu \mathrm{g} / \mathrm{m}^{3}$.

\subsubsection{Spatial distribution of $\mathrm{PM}_{10}$ calculated concentrations by CHIMERE/MM5 and CHIMERE/WRF for January}

Figure 4 shows the monthly mean spatial distribution of the $\mathrm{PM}_{10}$. Large differences between the model simulations using MM5 and WRF are found. For CHIMERE/MM5 (Fig. 4a) the model calculates a $\mathrm{PM}_{10}$ concentration around $40-50 \mu \mathrm{g} / \mathrm{m}^{3}$ for a large part over the Po valley, with elevated levels for the Milan city, up to $105 \mu \mathrm{g} / \mathrm{m}^{3}$.

In Fig. 4b, CHIMERE/WRF shows a much lower $\mathrm{PM}_{10}$ concentration over the Po valley area than CHIMERE/MM5 
(on average a factor 2 lower) and a concentration for the Milan city of $59 \mu \mathrm{g} / \mathrm{m}^{3}$. These differences are due to the difference in LHF and the resulting PBL heights caused by microphysics as described in Sect. 4.2.2. A sensitivity analysis showed that changing only the PBL scheme in WRF from YSU into MRF, does not improve the calculated $\mathrm{PM}_{10}$ concentrations for January.

Another important parameter responsible for the surface heat fluxes could be related to the choice of the land surface model.

We performed a sensitivity analysis by changing the Noah LSM scheme in WRF by the 5-layer soil temperature model and the YSU PBL with the MRF.

The $\mathrm{PM}_{10}$ spatial distribution and concentrations for this simulation improve in Fig. 4c. For the Po valley area $\mathrm{PM}_{10}$ concentrations are on average around $35-40 \mu \mathrm{g} / \mathrm{m}^{3}$, which is up to a factor of 1.6 higher than the simulation using WRF meteorology with the Noah land surface model and closer to the concentrations of CHIMERE/MM5 (CHIMERE/MM5 $20 \%$ higher) and correspond better to the observations in the Lombardy region. For the Milan city a monthly mean concentration of $79 \mu \mathrm{g} / \mathrm{m}^{3}$ is found, which is a factor 1.3 higher than with Noah LSM and is closer to CHIMERE/MM5. For the five stations, the $\mathrm{PM}_{10}$ concentrations are on average $41 \%$ higher than with Noah LSM and YSU PBL.

As described above, the choice of LSM has an impact on the heat fluxes and the resulting PBL heights, the vertical mixing and therefore in the aerosol concentration. The underlying reason for the improvement in $\mathrm{PM}_{10}$ concentrations is related to the change in PBL height with the 5 layer soil temperature LSM+MRF PBL scheme in respect to the PBL height with the Noah LSM. When we analyze for the stations the heat fluxes we see that the SHF with the 5-layer soil moisture LSM are on average a factor 2 lower than with the Noah LSM; on average $-13.6 \mathrm{~W} / \mathrm{m}^{2}$ with WRF 5-layer soil temperature and MRF PBL, while with Noah LSM an average of $-6.9 \mathrm{~W} / \mathrm{m}^{2}$ is calculated. However, $\mathrm{LH}$ fluxes are on average $2 \mathrm{~W} / \mathrm{m}^{2}$ higher using the 5-layer soil temperature LSM than with Noah LSM.

Analyzing the resulting PBL heights for the five stations using the 5-layer soil temperature LSM, we see that the PBL height at noon for Ispra, Erba and Cantu are a factor 2 lower than when the Noah LSM is used and are closer to the PBL heights calculated by MM5. This results in reducing the vertical mixing in the first layers, leading to higher aerosol concentrations at ground level.

When we change the Noah LSM scheme in our WRF preprocessing for the 5-layer soil temperature model and keep the YSU PBL scheme, calculated $\mathrm{PM}_{10}$ concentrations for January 2005 increase by $30 \%$ in respect to the simulation using Noah LSM.

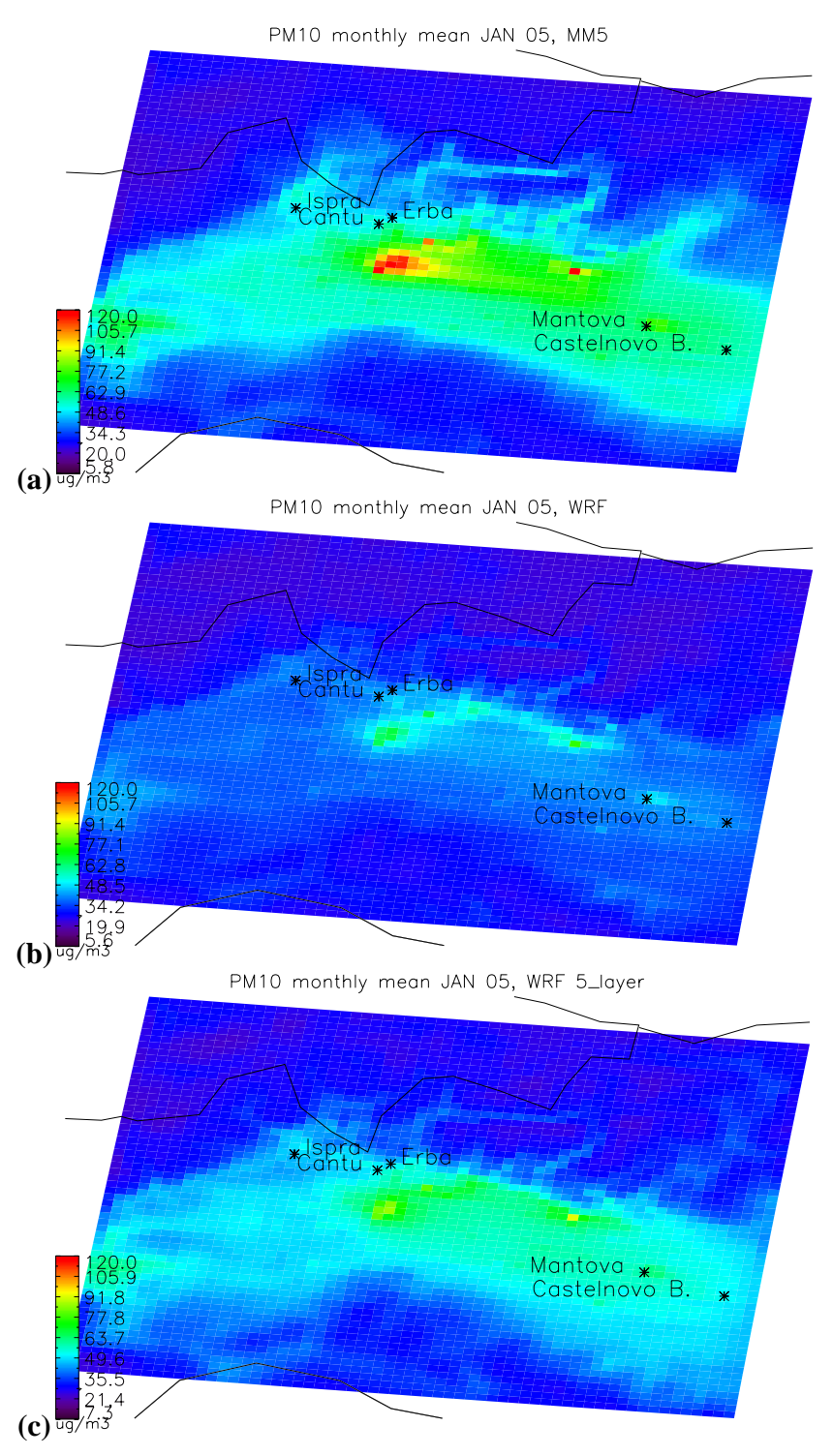

Fig. 4. Monthly mean $\mathrm{PM}_{10}$ concentrations for January by CHIMERE using the MM5 meteorology (a), WRF meteorology (b) and WRF meteorology using the 5-layer soil temperature model + MRF PBL scheme (c).

\subsubsection{Calculated PM 10 concentrations with MM5 and WRF for June}

In Table 6 we analyse the model results of the calculated monthly $\mathrm{PM}_{10}$ concentrations for June 2005 and compare them with observations for five stations in the Lombardy region.

For both model simulations the $\mathrm{PM}_{10}$ concentrations are in better agreement with the observations than in January. The model mean calculated concentrations by CHIMERE/MM5 (on average $29.9 \mu \mathrm{g} / \mathrm{m}^{3}$ ) and CHIMERE/WRF (on average $\left.30 \mu \mathrm{g} / \mathrm{m}^{3}\right)$ agree well with the observations $\left(29.2 \mu \mathrm{g} / \mathrm{m}^{3}\right)$. 
Table 6. Monthly mean $\mathrm{PM}_{10}$ concentrations calculated by the CHIMERE model using MM5 and WRF meteorology for June 2005, including the standard deviation and the temporal correlation coefficient, together with the measurements.

\begin{tabular}{llll}
\hline Name station & $\begin{array}{l}\text { Monthly mean June model with } \\
\text { MM5 } \mu \mathrm{g} / \mathrm{m}^{3} \pm \text { stdev.; correlation } \\
\text { coeff. }\end{array}$ & $\begin{array}{l}\text { Monthly mean June model with } \\
\text { WRF } \mu \mathrm{g} / \mathrm{m}^{3} \pm \mathrm{stdev} ; \text { correlation co- } \\
\text { eff. }\end{array}$ & $\begin{array}{l}\text { Monthly mean June observa- } \\
\text { tions } \mu \mathrm{g} / \mathrm{m}^{3} \pm \mathrm{stdev} .\end{array}$ \\
\hline Ispra & $27.0 \pm 7.07 ; 0.16$ & $25.7 \pm 7.94 ; 0.43$ & $20.1 \pm 8.29$ \\
Cantu & $26.9 \pm 6.67 ; 0.23$ & $28.9 \pm 8.02 ; 0.38$ & $31.8 \pm 11.7$ \\
Erba & $25.4 \pm 6.46 ; 0.33$ & $30.8 \pm 7.45 ; 0.44$ & $32.7 \pm 10.3$ \\
Mantova & $40.6 \pm 7.64 ; 0.31$ & $37.4 \pm 5.99 ; 0.26$ & $21.7 \pm 8.92$ \\
Castelnovo Bariano & $29.4 \pm 5.01 ; 0.11$ & $27.4 \pm 4.35 ; 0.34$ & 29.2 \\
Average & 29.9 & 30.0 & \\
\hline
\end{tabular}

Table 7. Monthly mean measured concentrations for Ispra of $\mathrm{SO}_{4}^{=}, \mathrm{NO}_{3}^{-}$and $\mathrm{NH}_{4}^{+}$, together with the model calculated mean concentrations using MM5 and WRF, for June 2005, including the standard deviation and the temporal correlation coefficient.

\begin{tabular}{|c|c|c|c|}
\hline Mean June 2005, Ispra & $\begin{array}{l}\text { EMEP measurement } \\
\mu \mathrm{g} / \mathrm{m}^{3} \pm \mathrm{stdev}\end{array}$ & $\begin{array}{l}\text { CHIMERE MM5 } \mu \mathrm{g} / \mathrm{m}^{3} \pm \text { stdev.; } \\
\text { correlation coeff. }\end{array}$ & $\begin{array}{l}\text { CHIMERE WRF } \\
\mu \mathrm{g} / \mathrm{m}^{3} \pm \text { stdev.; correla- } \\
\text { tion coeff. }\end{array}$ \\
\hline $\mathrm{SO}_{4}^{=}$ & $5.38 \pm 2.78$ & $5.00 \pm 1.64 ; 0.16$ & $5.65 \pm 1.56 ; 0.46$ \\
\hline $\mathrm{NO}_{3}^{-}$ & $1.31 \pm 1.09$ & $1.73 \pm 2.16 ; 0.22$ & $2.19 \pm 2.27 ; 0.22$ \\
\hline $\mathrm{NH}_{4}^{+}$ & $2.33 \pm 1.10$ & $2.07 \pm 1.07 ; 0.01$ & $2.46 \pm 1.07 ; 0.33$ \\
\hline Sum EC,OC, dust & $10.5 \pm 4.92$ & $3.73 \pm 1.11 ; 0.15$ & $4.16 \pm 1.43 ; 0.38$ \\
\hline
\end{tabular}

The temporal correlation coefficients by CHIMERE/WRF are larger than by CHIMERE/MM5. Calculated $\mathrm{SO}_{4}^{\overline{-}}$, and $\mathrm{NH}_{4}^{+}$concentrations are in good agreement with the observations, see Table 7. $\mathrm{SO}_{4}^{=}$CHIMERE/MM5 $\left(5.00 \mu \mathrm{g} / \mathrm{m}^{3}\right)$ and CHIMERE/WRF $\left(5.65 \mu \mathrm{g} / \mathrm{m}^{3}\right)$ are in a good agreement with the observations $\left(5.38 \mu \mathrm{g} / \mathrm{m}^{3}\right)$. $\mathrm{NO}_{3}^{-}$aerosol by CHIMERE/WRF is overestimated by a factor 1.7 and the monthly mean concentration by CHIMERE/MM5 is overestimated by a factor 1.3 when compared to the observations. The calculated monthly mean $\mathrm{NH}_{4}^{+}$concentrations by CHIMERE/MM5 and CHIMERE/WRF are in good agreement with the observations. However, as daily temperatures exceed $20^{\circ} \mathrm{C}$ in June, these measured concentrations should be considered as lower limit values, due to evaporation from the quartz filter, see Sect. 3.1 for the explanation. Analysing the PPM (sum of EC, BC and dust), we see that the model underestimates the measured PPM by a factor 2.8 (CHIMERE/MM5) and 2.5 (CHIMERE/WRF). A possible explanation for this is related to the emissions factors applied for $\mathrm{OC}$ and $\mathrm{EC}$ in the emission inventories and the underestimation of SOA formation as described before.

The differences in $\mathrm{PM}_{10}$ concentrations between the two model simulations are small, which is not the case for January as described before. The underlying reason for this is that difference in the heat fluxes between MM5 and WRF are not that large as seen for January; SHF by WRF is 7\% higher, LHF by WRF is $9 \%$ lower when compared to the heat fluxes calculated by MM5.
These smaller differences in the heat fluxes result in the small differences in PBL heights for the five different stations. The PBL heights, using MM5 and WRF, both with Noah LSM scheme, are on average $\pm 1407 \mathrm{~m}$ (MM5) and $\pm 1464 \mathrm{~m}$ (WRF) for June for the five stations at $2 \mathrm{p}$.m. These small variations in the PBL heights will not affect the vertical mixing in the first layers of the model and therefore not invoke a large difference in aerosol distribution between the two model simulations.

\subsubsection{Sensitivity analysis of $\mathbf{P M}_{10}$ calculations for January}

Our model simulations using MM5 and WRF meteorology showed underestimations in $\mathrm{PM}_{10}$ concentrations for January 2005. These could be related to the uncertainties in the emission inventories and the lack of natural and anthropogenic sources of PM. However, we observed also large differences in calculated aerosol concentrations between model simulations using MM5 and WRF meteorology, while the emission input does not change.

In this section we explain that the latter difference is related to the parameterizations in the meteorological preprocessing.

In Sect. 4.2.4 we have seen that changing the LSM in WRF from Noah to the 5-layer soil temperature model and the PBL scheme from YSU into MRF, increase the calculated $\mathrm{PM}_{10}$ concentrations on average to $41 \%$ for the five stations. 
Table 8. Monthly mean ozone values calculated by the CHIMERE model using MM5 and WRF meteorology for June 2005, together with the measurements and the correlation coefficients (based on hourly values), including the standard deviation and the temporal correlation coefficient.

\begin{tabular}{llllll}
\hline Name station & $\begin{array}{l}\text { Monthly mean } \\
\text { model with MM5 } \\
(\mathrm{ppb}) \pm \text { stdev. }\end{array}$ & $\begin{array}{l}\text { Monthly mean } \\
\text { model with WRF } \\
(\mathrm{ppb}) \pm \text { stdev }\end{array}$ & $\begin{array}{l}\text { Monthly mean } \\
\text { observations } \\
(\mathrm{ppb}) \pm \text { stdev }\end{array}$ & $\begin{array}{l}\text { Correlation } \\
\text { MM5 vs Obs }\end{array}$ & $\begin{array}{l}\text { Correlation WRF } \\
\text { vs. Obs }\end{array}$ \\
\hline Ispra & $46.4 \pm 8.34$ & $52.4 \pm 8.26$ & $35.3 \pm 5.83$ & 0.77 & 0.75 \\
Erba & $54.3 \pm 9.31$ & $56.8 \pm 9.79$ & $27.6 \pm 11.5$ & 0.60 & 0.51 \\
Osio Sotto & $42.2 \pm 8.76$ & $45.8 \pm 9.10$ & $50.1 \pm 11.9$ & 0.71 & 0.57 \\
Gambara & $50.1 \pm 7.70$ & $50.2 \pm 5.21$ & $49.5 \pm 9.24$ & 0.47 & 0.40 \\
Corte de Cortesi & $49.5 \pm 7.73$ & $50.1 \pm 6.26$ & $41.3 \pm 5.46$ & 0.75 & 0.65 \\
Marmirolo Fontana & $48.7 \pm 6.77$ & $49.8 \pm 4.67$ & $36.6 \pm 5.98$ & 0.70 & 0.57 \\
Lecco & $52.7 \pm 8.66$ & $63.5 \pm 9.78$ & $56.6 \pm 15.8$ & 0.46 & 0.63 \\
Varese & $41.3 \pm 6.85$ & $45.9 \pm 4.62$ & $53.6 \pm 13.2$ & 0.50 & 0.35 \\
Chiavenna & $49.3 \pm 4.19$ & $55.8 \pm 2.91$ & $49.3 \pm 12.4$ & 0.17 & 0.45 \\
Milano & $31.5 \pm 8.21$ & $29.5 \pm 5.90$ & $39.8 \pm 8.65$ & 0.68 & 0.41 \\
Average & 46.6 & 50.0 & 40.0 & 0.58 & 0.53 \\
\hline
\end{tabular}

A sensitivity analysis showed that changing only the PBL scheme in WRF from YSU into MRF, does not improve the calculated $\mathrm{PM}_{10}$ concentrations for January.

Another sensitivity analysis showed that changing the LSM model in MM5 from Noah to the 5-layer soil temperature model, sensible heat and latent heat fluxes change and to some extent the resulting PBL heights.

On average, the SHF for the five stations using the 5-layer soil temperature model is almost a factor 2 lower, i.e. $-14.6 \mathrm{~W} / \mathrm{m}^{2}$ (which corresponds with the average SHF using 5-layer soil temperature model in WRF, $-13.6 \mathrm{~W} / \mathrm{m}^{2}$ ), while with the Noah LSM, SHF is on average $-8.0 \mathrm{~W} / \mathrm{m}^{2}$, as described in Sect. 4.2.2. However, LHF goes up from $5.7 \mathrm{~W} / \mathrm{m}^{2}$ (Noah) to $11.2 \mathrm{~W} / \mathrm{m}^{2}$. This results in that the PBL height does not change as much as seen between MM5 and WRF and therefore aerosol concentrations does not change much (on average $2 \mu \mathrm{g} / \mathrm{m}^{3}$ for the Po valley area).

When the Simple Ice microphysics scheme in the MM5 simulation is changed for the Mixed Phase microphysics scheme, we see that the monthly mean $\mathrm{PM}_{10}$ concentrations are lower, up to $20 \%$. The underlying reason for this is that with the Mixed Phase scheme, more cloud liquid water is calculated by the model than with the Simple Ice scheme, which is responsible for lower $\mathrm{NO}_{3}$ aerosol peak values and the resulting $\mathrm{PM}_{10}$ values as described in Sect. 4.2.3.

\subsubsection{Calculated $\mathrm{O}_{3}$ concentrations with CHIMERE/ MM5 and CHIMERE/WRF for June}

In Table 8 the monthly mean $\mathrm{O}_{3}$ calculated values by CHIMERE/MM5 and CHIMERE/WRF are given for nine background stations, together with the observations and the correlation coefficients.

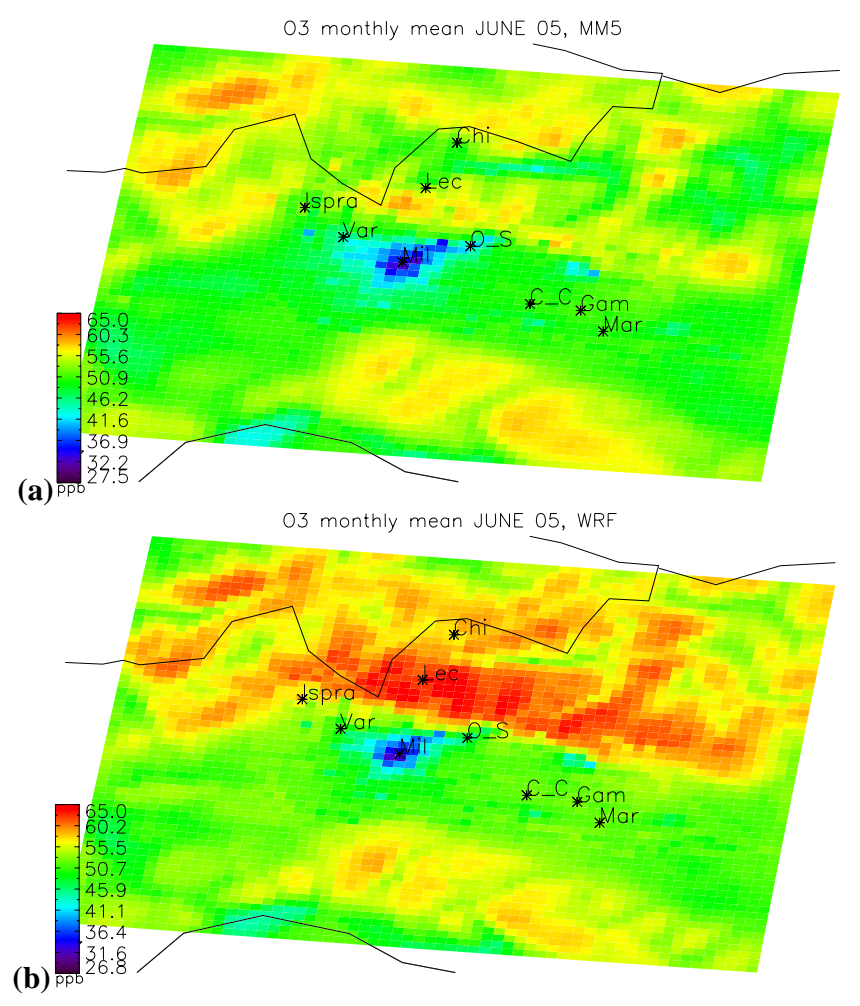

Fig. 5. Monthly mean $\mathrm{O}_{3}$ concentrations for June by CHIMERE using the MM5 meteorology (a) and WRF meteorology, Noah LSM and YSU PBL (b). Var $=$ Varese $, \mathrm{Lec}=\mathrm{Lecco}, \mathrm{Chi}=$ Chiavenna, O_S = Osio Sotto, C_C = Corte di Cortesi, Gam=Gambara, Mar $=$ Marmirolo Fontana, Mil = Milan.

Overall the monthly mean $\mathrm{O}_{3}$ values by CHIMERE are overestimated on average by a factor 1.3 for both using MM5 and WRF meteorology and the correlation coefficients are in 
general higher by CHIMERE/MM5. In Fig. 5a and 5b, the monthly (June) mean $\mathrm{O}_{3}$ concentrations by the CHIMERE model are shown, using MM5 and WRF meteorology. In general the concentrations in the Po Valley area are similar. However we observe differences in $\mathrm{O}_{3}$ values in the mountain regions, of around 6-9 ppb with a maximum up to $14 \mathrm{ppb}$. Analyzing the monthly mean wind direction and wind speed, we see that WRF monthly mean wind speed is $3 \mathrm{~m} / \mathrm{s}$, with a larger daily amplitude and frequency from south to north direction. The monthly mean wind speed by MM5 is $2 \mathrm{~m} / \mathrm{s}$, with lower daily velocity amplitude and a lower southnorth frequency. The larger wind speed by WRF transports the $\mathrm{O}_{3}$ from the Po valley area higher up over the mountains, resulting in higher $\mathrm{O}_{3}$ concentrations over this area. A similar effect of larger wind speeds on $\mathrm{O}_{3}$ concentrations over the Pre Alps has been observed earlier by Minguzzi et al. (2005).

Figure $6 \mathrm{a}-\mathrm{c}$ presents hourly average surface concentrations of $\mathrm{O}_{3}, \mathrm{NO}$ and $\mathrm{NO}_{2}$ for the complete month of June 2005. Due to its large-scale spatial representativity, the average of ozone concentration gives very good correlations between the model and observations (CHIMERE/MM5 0.96, CHIMERE/WRF 0.97). The diurnal cycle is well represented compared to the measurements. Before the sunrise (07:00 LT), the two models give different estimations: MM5 slightly underestimates the measurements $(\sim 5 \mathrm{ppb})$ when WRF slightly overestimates $(\sim 3 \mathrm{ppb})$. During the convective period (from 07:00 to 16:00 LT), the two models overestimate the ozone concentrations. After 16:00 LT, when the boundary layer collapses, the models again underestimates the surface concentrations.

In average, this may be explained by analyzing the surface $\mathrm{NO}$ and $\mathrm{NO}_{2}$ time series. Contrarily to ozone (secondary specie), these species are primary sources, depending on several activity sectors and are less spatially homogeneous. NO represents mainly the traffic source and this is explained by the morning peak (around 07:00 LT) when the nocturnal boundary layer remains thick: sources are not well mixed and the differences between models and measurements $(\sim 10 \mathrm{ppb})$ represent in the same time the uncertainty on the stable boundary layer estimation, the uncertainty on the emissions inventories knowledge, the uncertainty of the morning wind field and the subsequent advection and the spatial heterogeneity of these sources. The fact that the NO with MM5 is higher than measurements expresses the direct impact on the low underestimation of ozone for the same time period. At the end of the day, after 16:00 LT, the overestimation of modelled $\mathrm{NO}_{2}$ represents the end of the activity period for the traffic and probably a boundary layer certainly too low in average with the two meteorological models. These differences are often observed in CTM modeling and are the result of the uncertainty of meso-scale modeling to estimate accurately the unstable to stable boundary layer transition (including its time length and amplitude).
03 diurnal average June 05

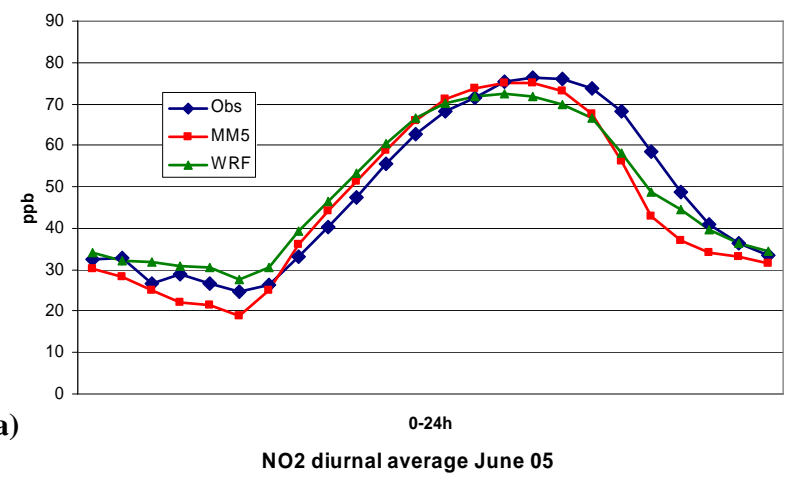

(b)

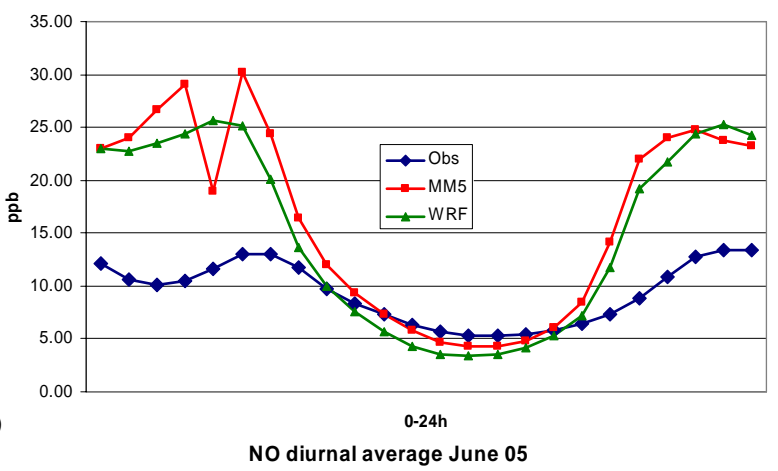

(c)

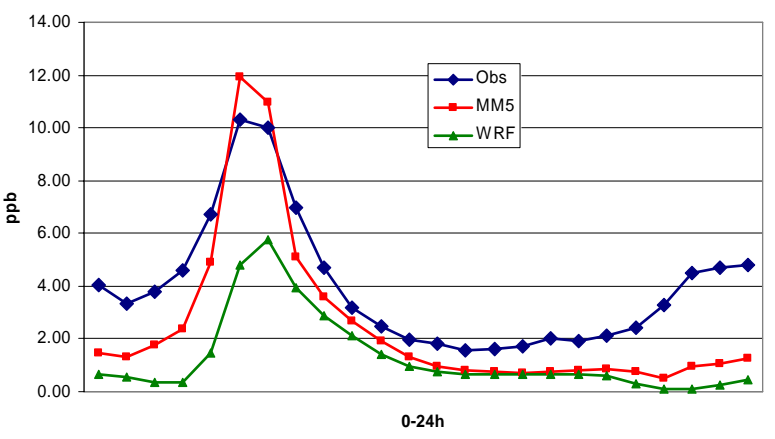

Fig. 6. Diurnal average of ozone (a), $\mathrm{NO}_{2}$ (b) and $\mathrm{NO}$ (c) for the observations (blue line) of the stations Ispra, Osio Sotto, Corte di Cortesi, Gambara and Varese, together with the calculated values by CHIMERE/MM5 (red line) and CHIMERE/WRF (green line), for June 2005.

\section{Summary and concluding remarks}

The impact of two different meteorological models (MM5 and WRF) on $\mathrm{PM}_{10}$, aerosols and $\mathrm{O}_{3}$ calculations over the Po valley region (Italy) for January and June 2005 is investigated.

First we evaluate for January, June and annually the calculated meteorological parameters by MM5 and WRF (temperature, wind speed, wind direction, relative humidity and precipitation) with observations. 
Overall we can say that the analysis of the meteorological modelling results shows that the performance of both models in calculating surface parameters is similar in all tested periods however differences are still observed. The temperatures are usually underestimated but in the most of cases within a BIAS range of $-3^{\circ} \mathrm{C}$. RMSE varies from 2 to $4.4^{\circ} \mathrm{C}$ and is lower than the SD calculated from observations. WRF usually produces higher temperature averages than MM5. The relative humidity is mainly overestimated but the BIAS values in most cases do not reach the level of $10 \%$ of RH. RMSE changes from about 12 to $20 \%$ (only for January the range is larger: from $\sim 10$ to $31 \%$ ) and the condition of RMSE $\mathrm{Rod}_{\text {mod }}<\mathrm{SD}_{\text {obs }}$, is fulfilled in most of cases also for this parameter. WRF produces higher averages of relative humidity than MM5 during the winter period. The wind field is not well reproduced due to difficulties caused by very low wind speeds occurring in the Po Valley area (average observed wind speeds over all analyzed periods were below $1 \mathrm{~m} / \mathrm{s}$ ). Both models overestimate largely the wind speed values with the BIAS higher than $2 \mathrm{~m} / \mathrm{s}$ and RMSE varying from 1.5 up to $3.3 \mathrm{~m} / \mathrm{s}$. The WRF model usually produces higher wind velocities than MM5. The observed prevailing wind direction is well reflected by the models for Ispra location, however, poorly reproduced for Mantova. The quantity of precipitation, according to statistics for the whole year, is overestimated by WRF and underestimated by MM5. The analysis of the hit rate statistics shows that WRF catches better the rain events.

The vertical potential temperature gradient profiles by WRF and MM5 correspond well to the observations from the Linate airport location for the whole year. This indicates that for this location both MM5 and WRF are able to reproduce the stability/instability of the atmosphere.

This study evaluates the impact of using two different meteorological models with the CHIMERE model on aerosol and $\mathrm{O}_{3}$ calculations for January and June 2005 .

In general the model underestimates the observed $\mathrm{PM}_{10}$ concentrations by a factor 2 (with MM5 meteorology) and 3 (with WRF meteorology) for January 2005. $\mathrm{NH}_{4}^{+}$is in good agreement with the observations for the Ispra EMEP station for both the models, whereas $\mathrm{NO}_{3}^{-}$using the MM5 meteorology is underestimated by a factor 1.4, but is in good agreement with observations using WRF. $\mathrm{SO}_{4}^{=}$is underestimated by a factor 2 and 1.5 by the model using MM5 and WRF respectively. However, the sum of EC, OM and anthropogenic dust is underestimated from the observations by the simulation using MM5 (by a factor 3) and WRF (by a factor 4).

The difference in $\mathrm{PM}_{10}$ concentrations for January between CHIMERE/MM5 and CHIMERE/WRF is around a factor $1.6\left(\mathrm{PM}_{10}\right.$ higher with MM5 meteorology). This difference and the larger underestimation in $\mathrm{PM}_{10}$ concentrations by CHIMERE/WRF are related to the differences in PBL heights calculated by WRF meteorology. In general the PBL height by WRF meteorology is a factor 2.8 higher at noon in January than calculated by MM5. This could result in a better vertical mixing of the aerosols than CHIMERE/MM5, causing lower aerosol concentrations at the surface.

The underlying reason for the differences in PBL heights can be explained by the differences found in the latent heat flux, which is responsible for the profile of the PBL, and the stronger temperature inversion effect by MM5. The WRF meteorology calculates a monthly mean latent heat flux which is a factor two larger than MM5.

The explanation for these differences in LHF is that the shortwave incoming radiation at the surface between MM5 and WRF is somehow different. In general more shortwave incoming radiation is observed by MM5 as a result of less cloud cover by MM5, which is caused by the difference in the microphysics scheme in MM5 and WRF.

This difference in microphysics scheme helps us to explain also the difference in $\mathrm{PM}_{10}$ peak values, which are observed between 14 and 18 January, as described in Sect. 4.2.3. In that section we explain that the presence of cloud liquid water (CLW) leads to the oxidation of $\mathrm{SO}_{2}$ into $\mathrm{SO}_{4}^{=}$aerosol. The absence of CLW at certain periods by MM5 (when WRF calculates $\mathrm{CLW}$ ) leads to the production of higher $\mathrm{NO}_{3}^{-}$concentrations, and the resulting higher $\mathrm{PM}_{10}$ concentrations.

Changing the Noah LSM scheme in our WRF preprocessing for the 5-layer soil temperature model, calculated $\mathrm{PM}_{10}$ concentrations for January 2005 increase by $30 \%$ in respect to the simulation using Noah LSM.

For June the differences in $\mathrm{PM}_{10}$ concentrations between the model simulations using MM5 and WRF are small. Compared to the observations, the model simulation using MM5 and WRF meteorology corresponds well with the observations $\left(29.2 \mu \mathrm{g} / \mathrm{m}^{3}\right)$. Analyzing the heat fluxes, the PBL height and PBL profile we observe small differences between the two meteorological models.

Analyzing the calculated $\mathrm{O}_{3}$ values for June, we see that for both the simulations the model overestimates on average by a factor 1.3 the measured $\mathrm{O}_{3}$ concentrations and the correlation coefficients are high. The higher $\mathrm{O}_{3}$ concentrations over the mountains with WRF meteorology could be related to the higher daily and more frequent south to north wind speed during day time than by MM5, bringing the $\mathrm{O}_{3}$ from the Milan area up to the mountains. Similar differences in calculated $\mathrm{O}_{3}$ concentrations were observed by Minguzzi et al. (2005). In this study the wind fields were varied, leading to higher ozone concentrations over the foothills of the Alps.

Underestimation of $\mathrm{PM}_{10}$ calculations is a common problem in air quality modelling (Van Loon et al., 2004; Schaap et al., 2007; Vautard et al., 2007; Stern et al., 2008). The underlying reason for this could be related to different factors contributing to the uncertainties in air quality modelling, such as uncertainties in the emission inventories, including the temporal and vertical distribution of the emissions (De Meij et al., 2006), the lack of natural and anthropogenic sources of PM (Schaap et al., 2004b), the role of the gas and aerosol boundary conditions on calculated aerosol concentrations in 
de model domain (De Meij et al., 2007) and the uncertainties in the meteorological parameters, such as mixing height and temperature (Hongisto, 2005) and wind fields (Minguzzi et al., 2005).

In the Po valley, especially during winter time, stagnant weather conditions are observed. These meteorological conditions are responsible for high PM concentrations. Low wind speeds and weak vertical mixing are responsible for these stagnant conditions, which are difficult to simulate with the meteorological models such as MM5 (Dosio et al., 2002; Minguzzi et al., 2005; Carvalho et al., 2006; Stern et al., 2008). This phenomenon was also encountered for the Milan city by the models in the Citydelta exercise (http: //aqm.jrc.it/citydelta, last accessed 12 March 2009; Cuvelier et al., 2006; Vautard et al., 2006).

This study showed the differences in meteorological parameters between two meteorological models over complex areas, especially during winter time periods. It shows how this affects the calculated gas and aerosol concentrations, which are non-linear dependent on meteorological conditions (Haywood and Ramaswamy, 1998; Penner et al., 1998; Easter and Peters, 1994).

The challenging task for the future is to improve the models' capability to simulate meteorological parameters, such as wind speed, wind direction, heat fluxes over complex terrain with a higher accuracy. This will improve, together with a more accurate emission inventory and better chemical mechanisms, the calculated gas and aerosol concentrations, which are necessary for scientific studies and for policy making.

Acknowledgements. The authors would like to thank E. Chaxel for the WRF interface in CHIMERE, J. L. Monge and S. Potempski for the additional support of the code, S. Galmarini for the valuable discussions. Also thanks to ARPA Lombardy and Veneto for the $\mathrm{PM}_{10}$ and meteorological measurements. The authors would like to thank the anonymous reviewers for the constructive comments. This work has been performed on the Beowulf Linux cluster of the Global Environment Monitoring Unit, Institute of Environment and Sustainability, JRC, Ispra (I).

Edited by: A. S. H. Prevot

\section{References}

Baertsch-Ritter, N., Prevot, A. S. H., Dommen, J., AndreaniAksoyoglu, S., and Keller, J.: Model study with UAM-Vin the Milan area (I) during PIPAPO: simulations with changed emissions compared to ground and airborne measurements, Atmos. Environ., 37, 4133-4147, 2003.

Baertsch-Ritter, N., Keller, J., Dommen, J., and Prevot, A. S. H.: Effects of various meteorological conditions and spatial emissionresolutions on the ozone concentration and ROG/ $\mathrm{NO}_{\mathrm{x}}$ limitationin the Milan area (I), Atmos. Chem. Phys., 4, 423-438, 2004, http://www.atmos-chem-phys.net/4/423/2004/.
Barna, M. and Lamb, B.: Improving ozone modeling in regions of complex terrain using observational nudging in a prognostic meteorological model, Atmos. Environ., 34, 4889-4906, 2000.

Bessagnet, B., Hodzic, A., Vautard, R., Beekman, M., Cheinet, S., Honeré, C., Liousse, C., and Rouil, L.: Aerosol modeling with CHIMERE - preliminary evaluation at the continental scale, Atmos. Environ., 38, 2803-2817, 2004.

Carvalho, A. C., Carvalho, A., Gelpi, I., Barreiro, M., Borrego, C., Miranda, A. I., and Pérez-Muñuzuri, V.: Influence of topography and land use on pollutants dispersion in the Atlantic coast of Iberian Peninsula, Atmos. Environ., 40, 3969-3982, 2006.

Chen, F. and Dudhia, J.: Coupling an advanced landsurface/ hydrologymodel with the Penn State/NCAR MM5 modeling system. Part I: Model description and implementation, Mon. Weather Rev., 129, 569-585, 2001.

Colella, P. and Woodward, P. R.: The Piecewise Parabolic Method (PPM) for Gas-Dynamical Simulations, J. Comp. Phys., 54, 174201, 1984.

Cuvelier, C., Thunis, P., Vautard, R., Amann, M., Bessagnet, B., Bedogni, M., Berkowicz, R., Brocheton, F., Builtjes, P., Denby, B., Douros, G., Graf, A., Honoré, C., Jonson, J., Kerschbaumer, A., de Leeuw, F., Moussiopoulos, N., Philippe, C., Pirovano, G., Rouil, L., Schaap, M., Stern, R., Tarrason, L., Vignati, E., Volta, L., White, L., Wind, P., and Zuber, A.: CityDelta: a model intercomparison study to explore the impact of emission reductions in European cities in 2010, Atmos. Environ., 41, 189-207, doi:10.1016/j.atmosenv.2006.07.036, 2007.

De Meij, A., Krol, M., Dentener, F., Vignati, E., Cuvelier, C., and Thunis, P.: The sensitivity of aerosol in Europe to two different emission inventories and temporal distribution of emissions, Atmos. Chem. Phys., 6, 4287-4309, 2006,

http://www.atmos-chem-phys.net/6/4287/2006/.

De Meij, A., Wagner, S., Gobron, N., Thunis, P., Cuvelier C., and Dentener, F.: Model evaluation and scale issues in chemical and optical aerosol properties over the greater Milan area (Italy), for June 2001, Atmos. Res., 85, 243-267, 2007.

Derognat, C., Beekmann, M., Baeumle, M., Martin, D., and Schmidt, H.: Effect of biogenic volatile organic compound emissions on tropospheric chemistry during the Atmospheric Pollution Over the Paris Area(ESQUIF) campaign in the Ile-de-France region, J. Geophys. Res., 108(D17), 8560, doi:10.1029/2001JD001421, 2003.

Dosio, A., Galmarini, S., and Graziani, G.: Simulation of the circulation and related photochemical ozone dispersion in the Po plains (northern Italy): comparison with the observations of a measuring campaign, J. Geophys Res., 107(D18), 8189, doi:10.1029/2000JD000046, 2002.

Dudhia, J.: Numerical study of convection observed during the winter monsoon experiment 10 using a mesoscale two-dimensional model, J. Atmos. Sci., 46, 3077-3107, 1989.

Dudhia, J.: A multi-layer soil temperature model For MM5. Preprints, The 6th PSU/NCAR Mesocale Model MM5 Users Workshop, Boulder, CO, 1996.

Easter, R. C. and Peters, L. K.: Binary Homogeneous Nucleation: Temperature and Relative Humidity Fluctuations, Nonlinearity, and Aspects of New Particle Production in the Atmosphere, J. Appl. Meteorol., 33, 775-784,1994

Fuchs, N. A.: The mechanics of aerosols, Pergamon Press, London, 1964. 
Ginoux, P., Chin, M., Tegen, I., Prospero, J. M., Holben, B., Dubovik, O., and Lin, S.-J.: Sources and distributions of dust aerosols simulated with the GOCART model, J. Geophys. Res., 106, 20255-20273, 2001.

Ginoux, P., Prospero, J. M., Torres, O., and Chin, M.: Longterm simulation of dust distribution with the GOCART model: Correlation with the North Atlantic Oscillation., Environ. Model. S., 19, 113-128, 2004.

Goeber, M. and Milton, S.: On the use of radar data to verify Mesoscale Model precipitation forecasts, Report of the SRNWP workshop on mesoscale verification 2001, 18-27, 2002a.

Grell, G. A., Dudhia, J., and Stauffer, D. R.: A description of the fifth-generation Penn State/NCAR mesoscale model (MM5), NCAR Tech. Note TN-398+STR, 122 pp, 1994.

Grosjean, D. and Seinfeld, J. H.: Parameterization of the formation potential of secondary organic aerosols, Atmos. Environ., 23, 1733-1747, 1989.

Guelle, W., Balkanski, Y. J., Dibb, J. E., Schulz, M., and Dulac, F.: Wet deposition in a global size-dependent aerosol transport model. 2. Influence of the scavenging scheme on $210 \mathrm{~Pb}$ vertical profiles, surface concentrations, and deposition, J. Geophys. Res., 103(D22), 28875-28891, 1998.

Guerrero, P. J., Jorba, O., Baldasano, J. M., and Gasso, S.: The use of a modelling system as a tool for air quality management: Annual high-resolution simulations and evaluation, Sci. Tot. Environ., 390, 323-340, 2008.

Haywood, J. M. and Ramaswamy, V.: Global sensitivity studies of the direct radiative forcing due to anthropogenic sulfate and black carbon aerosols, J. Geophys. Res., 103, 6043-6058, 1998.

Hong, S. Y. and Pan, H. L.: Nonlocal boundary layer vertical diffusion in a Medium-Range Forecast model, Mon. Weather Rev., 124, 2322-2339, 1996.

Hong, S.-Y., Noh, Y., and Dudhia, J.: A new vertical diffusion package with an explicit treatment of entrainment processes, Mon. Weather Rev., 134, 2318-2341, 2006.

Hong, S. Y. and Lim, J. O. J.: The WRF single-moment 6-class microphysics scheme (WSM6), J. Korean Meteor. Soc., 42, 129151, 2006.

Hong, S. Y., Noh, Y., and Dudhia, J.: A new vertical diffusion package with an explicit treatment of entrainment processes, Mon. Weather Rev., 134(9), 2318-2341, 2006.

Hongisto, M.: Uncertainties in the meteorological input of the chemistry-transport models and some examples of their consequences, Int. J. Environ. Pollut., 24 (1/2/3/4), pp. 127-153, 2005.

Horowitz, L. W., Walters, S., Mauzerall, D. L., Emmons, L. K., Rasch, P. J., Granier, C., Tie, X., Lamarque, J.-F., Schultz, M. G., Tyndall, G. S., Orlando, J. J., and Brasseur, G. P.: A global simulation of tropospheric ozone and related tracers: description and evaluation of MOZART, Version 2, J. Geophys. Res., 108(D24), 4784, doi:10.1029/2002JD002853, 2003.

Hov, O., Stordal, F., and Eliassen, A.: Photochemical oxidant control strategies in Europe: a 19 days case study using a Lagrangian model with chemistry, vol. TR5/95, NILU, 1985.

Jeuken, A.: Evaluation of chemistry and climate models using measurements and data assimilation, $\mathrm{PhD}$ thesis, Eindhoven University of Technology, 2000.

Kasibhatla, P., Chameides, W. L., and John, J. S.: A threedimensional global model investigation of seasonal variations in the atmospheric burden of anthropogenic sulphate aerosols, J.
Geophys. Res., 102, 3737-3759, 1997.

Kaufman, Y. J., Tanré, D., and Boucher, O.: A satellite view of aerosols in the climate system, Nature, 419, 215-223, 2002.

Kesarkar, A. P., Dalvi, M., Kaginalkar, A., and Ojha, A.: Coupling of the Weather Research and Forecasting Model with AERMOD for pollutant dispersion modeling. A case study for $\mathrm{PM}_{10}$ dispersion over Pune, India, Atmospheric Environment 41, 1976-1988, 2007.

Kulmala, M., Laaksonen, A., and Pirjola, L.: Parameterization for sulfuric acid/water nucleation rates, J. Geophys. Res., 103(D7), 8301-8307, 1998.

Lattuati, M.: Contribution à l'étude du bilan de l'ozone troposphérique à l'interface de l'Europe et de l'Atlantique Nord: modélisation lagrangienne et mesures en altitude, Thèse de sciences, Université Paris 6, France, 1997.

Lanz, V. A., Rami Alfarra, M., Baltensperger, U., Buchmann, B., Hueglin, C., Szidat, S., Wehrli, M. N., Wacker, L., Weimer, S., Caseiro, A., Puxbaum, H., and Prevot, A. S. H.: Source Attribution of Submicron Organic Aerosols during Wintertime Inversions by Advanced Factor Analysis of Aerosol Mass Spectra, Environ. Sci. Technol., 42, 214-220, 2008.

Loon van, M., Roemer, M., and Builtjes, P.: Model intercomparison in the framework of the review of the Unified EMEP model, TNO-Report R 2004/282, 2004.

Madronich, S. and Flocke, S.: The Role of Solar Radiation in Atmospheric Chemistry, Handbook of Environmental Chemistry, 1-26, 1998.

Maffeis, G.: Establishment of a yearly gas-PM emission inventory in the great Milan area, TerrAria s.r.l., contract no. 19536-200206 FISC ISP IT, Milan, 2003.

Menut, L., Coll, I., and Cautenet, S.: Impact of meteorological data resolution on the forecasted ozone concentrations during the ESCOMPTE IOP 2a and 2b, Atmos. Res. - ESCOMPTE Special Issue, 74, 139-159, 2005.

Michelson, S. A. and Bao, J.-W.: Comparison of two meteorological community models for air-quality applications. 14th Joint Conference on the Applications of Air Pollution Meteorology with the Air and Waste Management Association, available at: ams.confex.com/ams/pdfpapers/104587.pdf, 2006.

Minguzzi, E., Bedogni, M., Carnevale, C., and Pirovano, G.: Sensitivity of CTM simulations to meteorological input., Int. J. Environ. Pollut., 24, 36-50, 2005.

Mlawer, E. J., Taubman, S. J., Brown, P. D., Iacono, M. J., and Clough, S. A.: Radiative transfer for inhomogeneous atmospheres: RRTM, a validated correlated-k model for the longwave, J. Geophys. Res., 102(D14), 16663-16682, 1997.

Moshammer, H. and Neuberger, M.: The active surface of suspended particles as a predictor of lung function and pulmonary symptoms in Austrian school children, Atmos. Environ., 37, 1737-1744, 2002.

Moshammer, H. and Neuberger, M.: The active surface of suspended particles as a predictor of lung function and pulmonary symptoms in Austrian school children, Atmos. Environ., 37, 1737-1744, 2003.

Moucheron, M. C. and Milford, J.: Development and Testing of a Process Model for Secondary Organic Aerosols, Air and Waste Management Association, Nashville, 1996.

Nenes, A., Pilinis, C., and Pandis, S. N.: ISORROPIA: a new thermodynamic model for inorganic multicomponent atmospheric 
aerosols, Aquatic Geochemistry, 4, 123-152, 1998.

Odum, J. R., Hoffmann, T., Bowman, F., Collins, D., Flagan, R. C., and Seinfeld, J. H.: Gas/particle partitioning and secondary aerosol yield, Environ. Sci. Technol., 30, 2580-2585, 1996.

Odum, J. R., Jungkamp, T. P. W., Griffin, R. J., Flagan, R. C., and Seinfeld, J. H.: The atmospheric aerosol-forming potential of whole gasoline vapour, Science, 276, 96-99, 1997.

Pandis, S. N. and Seinfeld, J. H.: Sensitivity analusis of a chemical mechanism for aqueous-phase atmospheric chemistry, J. Geophys. Res., 94, 1105-1126, 1989.

Pankow, J. F.: An absorption model of gas/particle partitioning of organic compounds in the atmosphere, Atmos. Environ., 28, 185-188, 1994.

Pankow, J. F., Seinfeld, J. H., Asher, W. E., and Erdakos, G. B.: Modeling the formation of secondary organic aerosol. 1. Application of theoretical principles to measurements obtained in the a-pinene/, b-pinene/, sabinene, D3-carene/, and cyclohexene/ozone systems, Environ. Sci. Technol., 35, 1164-1172, 2001.

Penner, J. E., Chuang, C. C., and Grant, K.: Climate forcing by carbonaceous and sulfate aerosols, Clim. Dynam. 14, 839-851, 1998.

Pirovano, G., Coll, I., Bedogni, M., Alessandrini, S., Costa, M. P., Gabusi, V,. Lasry, F., Menut, L., and Vautard, R.: On the influence of meteorological input on photochemical modelling of a severe episode over a costal area, Atmos. Environ., 41, 64456464, doi:10.1016/j/atmosenv.2007.04.001, 2007.

Robinson, A. L., Donahue, N. M., Shrivastava, M. K., Weitkamp, E. A., Sage, A. M., Grieshop, A. P., Lane, T. E., Pierce, J. R., and Pandis, S. N.: Rethinking Organic Aerosols: Semivolatile Emissions and Photochemical Aging, Science, 315, 1259-1262, 2007

Schaap, M.: On the importance of aerosol nitrate in Europe, Data analysis and modelling, Ph.D. thesis, University of Utrecht, http://www.library.uu.nl/digiarchief/dip/diss/ 2003-1209-110044/inhoud.htm, 2003.

Schaap, M., van Loon, M., ten Brink, H. M., Dentener, F. J., and Builtjes, P. J. H.: Secondary inorganic aerosol simulations for Europe with special attention to nitrate, Atmos. Chem. Phys., 4, 857-874, 2004a, http://www.atmos-chem-phys.net/4/857/2004/.

Schaap, M., Denier van der Gon, H. A. C., Visschedijk, A. J. H., Van Loon, M., ten Brink, H. M., Dentener, F. J., Putaud, J.-P., Guillaume, B., Liousse, C., and Builtjes, P. J. H.: Anthropogenic black carbon and fine aerosol distribution over Europe, J. Geophys. Res., 109, D18201, doi:10.1029/2003JD004330, 2004b.

Schaap, M., Vautard, R., Bergström, R., van Loon, M., Bessagnet, B., Brandt, J., Christensen, J., Cuvelier, K., Foltescu, V., Graff, A., Jonson, J., Kerschbaumer, A., Krol, M., Langner, J., Roberts, P., Rouil, L., Stern, R., Tarrason, L., Thunis, P., Vignati, E., White, L., Wind, P., and Builtjes, P.: Evaluation of long term aerosol simulations from seven regional air quality models and their ensemble in the EURODELTA study, Atmos. Environ., 41, 2083-2097, 2007.

Schell, B., Ackermann, I. J., Hass, H., Binkowski, F. S., and Ebel, A.: Modeling the formation of secondary organic aerosol within a comprehensive air quality model system, J. Geophys. Res., 106(D22), 28275-28293, 2001.
Schmidt, H., Derognat, C., Vautard, R., and Beekmann, M.: A comparison of simulated and observed ozone mixing ratios for the summer of 1998 in Western Europe, Atmos. Environ., 35(36), 6277-6297, 2001.

Seinfeld, J. H. and Pandis, S. N.: Atmospheric Chemistry and Physics, Wiley, New York, 1998.

Skamarock, W. C., Klemp, J. B., Dudhia, J., Gill, D. O., Barker, D. M., Wang, W., Powers, J. G.: A Description of the Advanced Research WRF Version 2., NCAR Technical Note 468+STR, Mesoscale and Microscale Meteorology Division, NCAR, Boulder, Colorado, USA, June 2005.

Stephenson, D. B.: Use of the "odds ratio" for diagnosing forecast skill., Wea. Forecasting, 15, 221-232, 2000.

Stern, R., Builtjes, P., Schaap, M., Timmermans, R., Vautard, R., Hodzic, A., Memmesheimer, M., Feldmann, H., Renner, E., Wolke, R., and Kerschbaumer, A.: A model inter-comparison study focussing on episodes with elevated $\mathrm{PM}_{10}$ concentrations, Atmos. Environ., 42(19), 4567-4588, 2008.

Stull, R.: An Introduction to Boundary Layer Meteorology, Kluwer Academic Publishers, 1988.

Soong, S.-T., Martien, P. T., Archer, C. L., Tanrikulu, S., Wilczak, J. M., Bao, J.-W., Michelson, S. A., Jia, Y., and Emery, C. A.: Comparison of WRF/CAMx and MM5/CAMx simulations for an ozone episode in California, Eighth Conference on Atmospheric Chemistry, Atlanta, Georgia, 29 January-2 February 2006.

Taylor, K. E.: Summarizing multiple aspects of model performance in a single diagram, J. Geophys. Res., 106, 7183-7192, 2001.

Thunis, P., Rouil, L., Cuvelier, C., Bessagnet, B., Builtjes, P., Douros, J., Kerschbaumer, A., Pirovano, G., Schaap, M., Stern, R., and Tarrason, L.: Analysis of large and fine scale model responss to emission-reduction scenarios within the CityDelta project, Atmos. Environ., 41(10), 2083-2097, 2007.

Troen, I. and Mahrt, L.: A simple model of the atmospheric boundary layer: Sensitivity to surface evaporation, Bound.-Lay. Meteorol., 37, 129-148, 1986.

Tsyro, S.: First estimates of the effect of aerosol dynamics in the calculation of $\mathrm{PM}_{10}$ and $\mathrm{PM}_{2.5}$, EMEP Report (http://www. emep.int), 2002.

Vautard, R., Builtjes, P., Thunis, P., Cuvelier, K., Bedogni, M., Bessagnet, B., Honore', C., Moussiopoulos, N., Schaap, M., Stern, R., Tarrason, L., and van Loon, M.: Evaluation and intercomparison of Ozone and $\mathrm{PM}_{10}$ simulations by several chemistry-transport models over 4 European cities within the City-Delta project, Atmos. Environ., 41, 173-188, 2007.

Wesely, M. L.: Parameterization of surface resistances to gaseous dry deposition in regional-scale numerical models, Atmos. Environ., 23, 1293-1304, 1989.

West, J. J., Pilinis, C., Nenes, A., and Pandis, S. N.: Marginal direct climate forcing by atmospheric aerosols, Atmos. Environ., 32, 2531-2542, 1998.

Zhong, S., In, H., and Clements, C.: Impact of turbulence, land surface, and radiation parameterizations on simulated boundary layer properties in a coastal environment, J. Geophys. Res., 112, D13110, doi:10.1029/2006JD008274, 2007. 